\title{
Review of Cardiovascular Disease in HIV-Infected Women
}

Ruth Adekunle and Shashwatee Bagchi*

University of Maryland School of Medicine, Baltimore, MD, USA

\begin{abstract}
Rates of coronary heart disease (CHD) are over twice as high in younger HIV-infected patients compared to uninfected patients, but most of these studies were conducted in men or in predominantly male cohorts. In the general population, the death rate from CHD has decreased among men, but continues to increase in women. It is unclear if the same increased rate of deaths due to CHD exist in HIV-infected women, and whether rates or risk of CHD differ between HIV-infected men and women, and between seropositive and seronegative women. We reviewed the literature on the rates of cardiovascular events and surrogate measures of atherosclerosis or CHD risk in HIV-infected women. We also reviewed rates of metabolic disease and other markers of inflammation and immune activation that could contribute to increased cardiovascular risk. We found that HIV-infected women have increased rates of acute myocardial infarctions and ischemic strokes compared to HIV-uninfected women and likely HIV-infected men despite women being projected to have lower CHD risk based on Framingham risk scores. Studies assessing CHD risk by measuring anatomical or physiological measures of subclinical atherosclerosis have reported mixed results, and there are no well-validated risk assessment tools or surrogate measures of subclinical CHD among HIV-infected patients to help identify high-risk women for targeting intensive preventive measures. Potential explanations for the increased rates of CHD and subclinical atherosclerosis may be partly explained by increased levels of inflammation and immune activation in HIV-infected women despite virological suppression on antiretroviral therapy. It appears unlikely that disproportionate representation of traditional CHD risk factors and metabolic indices among HIV-infected women can explain well the observed increased rates of CHD. Future studies that include large numbers of HIV-infected women with extended follow-up periods using surrogate measure of CVD and investigating pathogenic mechanisms underlying these observations are urgently needed.
\end{abstract}

Keywords: Cardiovascular disease and HIV and women; Subclinical cardiovascular disease and HIV and women; HIV and cardiovascular disease risk; Coronary heart disease and HIV and women; Acute myocardial infarction and HIV and women; Framingham risk and HIV and women; HIV and women; HIV/AIDS

\section{Introduction}

Individuals infected with Human Immunodeficiency Virus (HIV) are now living longer due to improved and expanded access to antiretroviral therapy (ART). However, all-cause mortality rates continue to be higher in HIV-infected patients than in the general population and there has been an increased percentage of non-AIDSdefining illnesses [1]. Coronary heart disease (CHD) represents the second cause of death among HIV-infected patients currently, and is expected to increase as the population ages [2].

Numerous studies report increased risk of CHD in HIV-infected people, but most of these studies were conducted in men or in predominantly male cohorts [3-5]. In the general population, men have been reported to have higher rates of CHD and at younger age than women [6,7]. The death rate from cardiovascular disease (CVD) has decreased among men, but continues to increase in women [8]. Recent statistics show that 42 percent of women who have heart attacks die within one year compared with 24 percent of men. As such, there has been increased attention in the scientific community as well as the general media surrounding missed opportunities to accurately diagnose CHD early and intervene in timely manner among women. It is unclear if the same increased rate of deaths due to CHD exist in HIV-infected women, and whether rates or risk of CHD differ between HIV-infected men and women, and between seropositive and seronegative women.

The purpose of our review was several-fold. We reviewed the literature on the rates of cardiovascular events and surrogate measures of atherosclerosis or CHD risk in HIV-infected women. We also reviewed rates of metabolic disease and other markers of inflammation and immune activation that could contribute to increased cardiovascular $(\mathrm{CV})$ risk.

\section{Methods}

We searched PubMed and Embase for English-language articles published from January 1, 2005 - October 27th, 2015 using search terms "Cardiovascular disease, HIV, Women," "Coronary heart disease, HIV, Women," "Framingham risk and HIV and women," "Acute MI, women, and HIV", and "Acute myocardial infarction, HIV, and women. We also searched using terms "Carotid intimal thickness, HIV, women" and "Coronary atherosclerosis, HIV, women." A total of 323 references were found, but 213 references were not selected because they were abstracts, poster presentations, correspondences, letters, or other report types. 76 more studies were excluded after reading the abstracts because they did not have findings specific to HIV-infected women. Four studies were removed from the review because they did not contribute any additional information than those included. Four were reviewed in the manuscript text but not included in the tables because they reported sample sizes of less than 100 participants. 12 relevant studies were included from references of selected manuscripts.

*Corresponding author: Shashwatee Bagchi, MD, MS, Institute of Human Virology and Division of Infectious Diseases, University of Maryland School of Medicine, 725 West Lombard Street, N359, Baltimore, MD 21201, USA, Tel: 410706-4606; E-mail: sbagchi@som.umaryland.edu

Received November 27, 2015; Accepted March 03, 2016; Published March 15, 2016

Citation: Adekunle R, Bagchi S (2016) Review of Cardiovascular Disease in HIVInfected Women. J AIDS Clin Res 7: 557. doi:10.4172/2155-6113.1000557

Copyright: (c) 2016 Adekunle R, et al. This is an open-access article distributed under the terms of the Creative Commons Attribution License, which permits unrestricted use, distribution, and reproduction in any medium, provided the original author and source are credited. 
Citation: Adekunle R, Bagchi S (2016) Review of Cardiovascular Disease in HIV-Infected Women. J AIDS Clin Res 7: 557. doi:10.4172/21556113.1000557

A total of 37 full-length articles were included in the final review (Figure 1). Of note, there were two studies included in our review that reported on more than one end point, and therefore they appear in more than one table. Selected studies were presented in the tables and the remainder were described in the section corresponding to the relevant endpoint or risk factor for CHD discussed.

Study designs included one randomized clinical trial, 13 prospective observational cohorts, one retrospective analyses, 18 cross-sectional studies, and four case-control studies. Endpoints assessed were: CHD incidence and mortality, risk scores to assess risk for developing CVD, anatomical and physiological surrogate markers of CVD including carotid intimal media thickness (CIMT), pulse wave velocity (PWV), computed tomography coronary angiography (CTA) and ankle-brachial index (ABI), biomarkers of CVD, and alterations of the metabolic profile. Adjusted odds ratio $(\mathrm{OR})$, hazard ratio (HR), relative risk (RR), along with associated confidence intervals $(\mathrm{CI})$ and $\mathrm{p}$-values were extracted and reported from all studies whenever available.

\section{Results}

\section{Clinical outcomes}

The cardiovascular events reported in studies include acute myocardial infarction (AMI), unstable angina, ischemia heart failure, and ischemic stroke. Table 1 summarizes the six studies that reported clinical cardiovascular outcomes in HIV-infected women. In a study from the Partners HealthCare System of 3851 HIV-infected patients including 1172 women, there was RR of 2.98 (95\% CI 2.33, 3.75; $\mathrm{p}<0.0001$ ) of developing AMI for HIV-infected women compared to seronegative women whereas HIV-infected men had RR of 1.40 (95\% CI 1.16, 1.67; $\mathrm{p}=0.0003$ ) compared to seronegative men [9]. The Veterans Aging Cohort Study that included 2187 HIV-infected women demonstrated that incident CHD per 1000 person-years was significantly higher among HIV-infected women with incident rate (IR) 13.5 (95\% CI 10.1, 18.1) compared to uninfected women with IR 5.3 (95\% CI 3.9, 7.3; $\mathbf{p}<0.001)$. In addition, the median age to first CHD event was 49.3 years vs. 51.2 years for HIV-infected female veterans compared to HIV-uninfected female veterans $(p=0.05)$ [10]. Similarly, a French study showed that the risk of MI was higher in both HIVinfected men and women, but the standardized morbidity ratio for HIV-infected women was 2.7 compared to 1.4 for HIV-infected men [11]. Chow et al. demonstrated that HIV-infected women have higher rates of ischemic stroke compared with HIV-infected men with HR 2.16 (95\% CI 1.53, 3.04; $\mathrm{p}<0.001)$ for women vs. HR 1.18 (95\% CI 0.95 , 1.47; $\mathrm{p}=0.14$ ) for men [12]. These studies confirm that HIV-infected women have increased rates of CHD compared to HIV-uninfected women, and in some instances may carry a greater risk of CHD than HIV-infected males.

\section{Surrogate measures of cardiovascular disease}

There are several risk assessment tools and non-invasive anatomical and physiological surrogate measures of CVD developed to assess the risk of developing CHD in the general population [13]. There were 28 studies reporting on risk scores to assess CVD or at least one surrogate

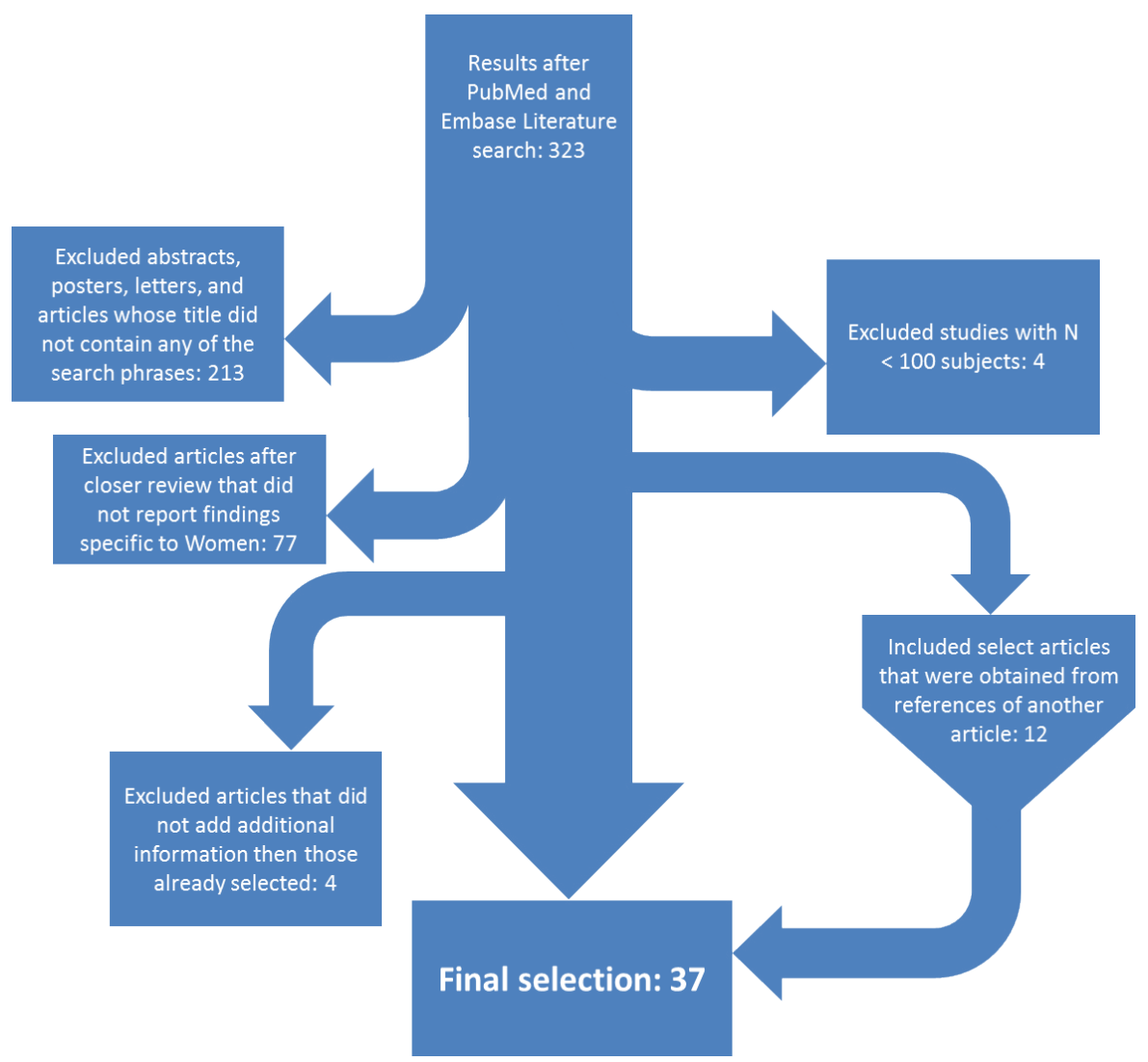

Figure 1: Article selection process of literature review. 
Citation: Adekunle R, Bagchi S (2016) Review of Cardiovascular Disease in HIV-Infected Women. J AIDS Clin Res 7: 557. doi:10.4172/21556113.1000557

Page 3 of 12

\begin{tabular}{|c|c|c|c|c|c|}
\hline Study & Design & N Study Population & Outcome & Follow up (months) & Results \\
\hline $\begin{array}{l}\text { Triant et al. } \\
\text { [9]. }\end{array}$ & $\begin{array}{l}\text { Prospective, } \\
\text { observational } \\
\text { cohort }\end{array}$ & $\begin{array}{l}3851 \text { HIV-infected } \\
\text { and HIV-uninfected } \\
1,044,589 \\
\text { Urban, hospital- } \\
\text { based, multicenter, } \\
\text { Mass }\end{array}$ & $\begin{array}{l}\text { AMI rates among } \\
\text { HIV-infected patients } \\
\text { compared to HIV- } \\
\text { uninfected patients }\end{array}$ & $\begin{array}{l}\text { HIV Cohort with } \\
16,983 \text { PY }(5,430 \\
\text { PYs were women), } \\
\text { non-HIV cohort } \\
\text { with } 3,747,329 \text { PY } \\
(2,217,127 \text { women } \\
\text { PY) in } 92 \text { months } \\
\text { follow up }\end{array}$ & $\begin{array}{l}\text {-AMI occurred in } 189 \text { HIV patients and in } 26,142 \text { HIV-uninfected } \\
\text { patients } \\
\text {-Rates of AMI were } 11.13 \text { per } 1000 \mathrm{PY}(95 \% \mathrm{Cl} 9.6,12.7) \text { in HIV } \\
\text { vs } 6.98 \text { per } 1000 \mathrm{PY} \text { in HIV-uninfected } \\
\text { - Unadjusted rates of AMI were } 12.71 \text { per } 1000 \mathrm{PY} \text { in HIV- } \\
\text { infected women vs. } 4.88 \text { per } 1000 \mathrm{PY} \text { for HIV-uninfected women } \\
\text { - No difference in rates of AMI was found in HIV-infected vs HIV- } \\
\text { uninfected men }\end{array}$ \\
\hline $\begin{array}{l}\text { Womack et al. } \\
\text { [10]. }\end{array}$ & $\begin{array}{l}\text { Prospective, } \\
\text { longitudinal, } \\
\text { observational } \\
\text { cohort }\end{array}$ & $\begin{array}{l}710 \text { HIV-infected } \\
\text { women, } 1477 \text { HIV- } \\
\text { uninfected women } \\
\text { Urban, hospital- } \\
\text { based, multicenter, } \\
\text { Yale, Pittsburgh, and } \\
\text { Connecticut }\end{array}$ & $\begin{array}{l}\text { Rates of AMI, unstable } \\
\text { angina, ischemic } \\
\text { stroke, and congestive } \\
\text { heart failure in HIV- } \\
\text { infected compared to } \\
\text { HIV-uninfected women }\end{array}$ & 72 months & $\begin{array}{l}\text {-Total of } 86 \text { incident CVD events. } 53 \% \text { of CVD events occurred } \\
\text { in HIV-infected women } \\
\text {-Incident CVD per } 1000 \mathrm{PY} \text { was significantly higher among HIV- } \\
\text { infected: IR } 13.5(95 \% \mathrm{Cl} 10.1,18.1) \text { vs IR } 5.3(95 \% \mathrm{Cl} 3.9,7.3 \text {; } \\
p<0.001) \text { HIV-uninfected } \\
\text {-HIV-infected women had an increased risk of CVD compared to } \\
\text { HIV-uninfected women, HR } 2.8(95 \% \mathrm{Cl} 1.7,4.6 ; p<0.001)\end{array}$ \\
\hline $\begin{array}{l}\text { Lang et al. } \\
\text { [11]. }\end{array}$ & $\begin{array}{l}\text { Nested case } \\
\text { control study }\end{array}$ & $\begin{array}{l}74,958 \text { HIV-infected } \\
\text { persons } \\
\text { Hospital-based in } \\
\text { three regions of } \\
\text { France }\end{array}$ & $\begin{array}{l}\text { Incidence of MI in the } \\
\text { HIV-infected population } \\
\text { compared to the } \\
\text { general population }\end{array}$ & $\begin{array}{l}\text { HIV cohort with } \\
298,156 \text { PY follow up } \\
\text { (207,300 PYs were } \\
\text { men and } 90,856 \text { PYs } \\
\text { were women) in } 72 \\
\text { months }\end{array}$ & $\begin{array}{l}-360 \text { cases of MI ( } 325 \text { men, } 35 \text { women) among the HIV-infected } \\
\text { patients. IR of } 1.24 \text { per } 1000 \text { PYs } \\
\text {-Risk of MI was higher in both HIV-infected men and women } \\
\text { than in the general population, with SMRs of } 1.4(95 \% \mathrm{Cl} 1.3 \text {, } \\
1.6) \text { for men and } 2.7(95 \% \mathrm{Cl} 1.8,3.9) \text { for women }\end{array}$ \\
\hline $\begin{array}{l}\text { Chow et al. } \\
\text { [12]. }\end{array}$ & $\begin{array}{l}\text { Prospective } \\
\text { observational } \\
\text { cohort }\end{array}$ & $\begin{array}{l}2958 \text { HIV-infected } \\
\text { men and } 1350 \text { HIV- } \\
\text { infected women } \\
\text { Urban, hospital- } \\
\text { based, multicenter, } \\
\text { Mass }\end{array}$ & $\begin{array}{l}\text { Incidence of ischemic } \\
\text { stroke among HIV- } \\
\text { infected patients } \\
\text { compared to HIV- } \\
\text { uninfected patients }\end{array}$ & $\begin{array}{l}\text { HIV cohort with } \\
233,700 \text { PYs follow } \\
\text { up in } 69 \text { months and } \\
\text { non-HIV with } 206,600 \\
\text { PYs follow up in } 76 \\
\text { months }\end{array}$ & $\begin{array}{l}\text {-Ischemic strokes in } 914 \text { patients, } 132 \mathrm{HIV} \text { and } 782 \text { non-HIV } \\
\text { - The IR of ischemic stroke was } 5.27 \text { per } 1000 \mathrm{PY} \text { in HIV-infected } \\
\text { patients vs } 3.75 \text { per } 1000 \text { PY in HIV-uninfected patients } \\
\text { - HIV-infection was significantly associated with ischemic } \\
\text { strokes for women with HR } 2.16(95 \% \mathrm{Cl} 1.53,3.04 ; p<0.001) \text {, } \\
\text { but not in men with HR } 1.18(95 \% \mathrm{Cl} 0.95,1.47 ; p=0.14)\end{array}$ \\
\hline $\begin{array}{l}\text { Hessamfar- } \\
\text { Bonarek et al. } \\
\text { [57]. }\end{array}$ & $\begin{array}{l}\text { Prospective } \\
\text { study }\end{array}$ & $\begin{array}{l}766 \text { HIV-infected } \\
\text { males and } 247 \text { HIV- } \\
\text { infected women } \\
\text { Hospital-based, } \\
\text { multicenter, France }\end{array}$ & $\begin{array}{l}\text { Changes in patterns of } \\
\text { gender-specific causes } \\
\text { of death between } 2000 \\
\text { and } 2005 .\end{array}$ & 60 months & $\begin{array}{l}-1013 \text { HIV-infected adults who died in } 2005 ; 247(24 \%) \text { were } \\
\text { women } \\
\text {-In } 2005 \text {, AIDS-defining causes of death was higher in women } \\
\text { than in men ( } 43 \text { vs } 34 \% ; p=0.01) \text {, whereas it had been the same } \\
\text { in } 2000 \text { ( } 47 \% \text { in women and men) } \\
\text {-In } 2005, \text { women died less frequently than men from } \\
\text { cardiovascular disease }(9 \% \text { of all causes of death in women } \\
\text { compared with } 16 \% \text { in men; } p=0.004)\end{array}$ \\
\hline $\begin{array}{l}\text { French et al. } \\
\text { [2]. }\end{array}$ & $\begin{array}{l}\text { Prospective, } \\
\text { longitudinal } \\
\text { cohort }\end{array}$ & $\begin{array}{l}710 \text { HIV-infected } \\
\text { women died } \\
\text { Urban, multicenter, } \\
\text { USA }\end{array}$ & $\begin{array}{l}\text { Temporal trends, } \\
\text { causes and predictors } \\
\text { of mortality }\end{array}$ & 120 months & $\begin{array}{l}-712 \text { HIV-infected patients died } \\
\text {-Death rate was } 8.0 \text { per } 100 \text { PY in } 1996, \text { but decreased to mean } \\
\text { rate of } 2.6 \text { per } 100 \text { PY in } 2001 \text { through } 2004 \\
\text {-Cardiovascular mortality was the second leading cause of non- } \\
\text { AlDS deaths }\end{array}$ \\
\hline
\end{tabular}

Mass: Massachusetts; AMI: Acute Myocardial Infarction; PY: Person-Years; Cl: Confidence Interval; CVD: Cardiovascular Disease; IR: Incidence rate; HR: Hazard ratio SMR: Standardized Morbidity Ratios

Table 1: Studies assessing cardiovascular disease clinical outcomes.

measure of CVD in HIV-infected women. Table 2 lists selected studies that used these risk assessment tools and surrogate measures of subclinical CVD in the HIV population.

Risk scores to assess CVD risk: There were 11 studies included that reported on the Framingham risk scores (FRS) in HIV-infected women. The Framingham risk score has been the most common risk assessment tool used to evaluate the risk of developing CHD in HIV-infected men and women. Studies demonstrate that HIV-infected women have low Framingham risk scores $[10,14,15]$, but there are no studies validating the FRS in this population. The Data Collection on Adverse Events of Anti-HIV Drugs (DAD) equation was derived to assess the potential increased risk of CHD in HIV-infected people using combination ART. Law et al. estimated the 3-year risk of myocardial infarction (MI) using the DAD equation in HIV-infected men and HIV-infected women and found that it was higher in men than in women, $0.92 \%(0.47 \pm$ $1.42 \%)$ vs. $0.07 \%(0.05 \pm 0.19 \%)$ [16]. Given the increased rates of CHD reported among HIV-infected women compared to HIV-infected men and to seronegative patients as described above, there is significant concern that the FRS and DAD equation may not be an accurate risk assessment tool for this patient population.

Carotid intimal media thickness (CIMT): There were 11 studies included evaluating CIMT in HIV-infected women. Carotid Intimal
Medial Thickness can be a useful marker of atherosclerosis and has been shown to correlate with CV risk factors and predict stroke and myocardial infarction in the general population [17]. Results of CIMT in HIV-infected women have been mixed with a few studies finding no significant difference between HIV-infected females and HIVuninfected females $[15,18]$. Increased CIMT has been associated with several CV risk factors, however. One study of $97 \mathrm{HIV}$-infected women noted that participants receiving protease inhibitors (PI) had increased CIMT compared to those not receiving PIs [18]. Another study found that in untreated HIV-infected women, there were no significant associations between lipid levels and CIMT, but in treated women higher levels of low-density lipoprotein cholesterol (LDL-c) and nonhigh density lipoprotein cholesterol (non-HDL-c) were associated with higher CIMT values [19]. Mangili et al. found that significantly more HIV-infected women than men had metabolic syndrome, and the mean common CIMT measurement was significantly higher among participants with metabolic syndrome than among those without metabolic syndrome (0.66 $\mathrm{mm}$ vs. $0.59 \mathrm{~mm}$; $\mathrm{p}=0.005)$ [20]. The association between HIV infection, CV risk factors and CVD remains unclear based on the available studies in HIV-infected women.

Pulse wave velocity (PWV): Pulse wave velocity is a surrogate marker of arterial stiffness that has been associated with CVD and 
Citation: Adekunle R, Bagchi S (2016) Review of Cardiovascular Disease in HIV-Infected Women. J AIDS Clin Res 7: 557. doi:10.4172/21556113.1000557

Page 4 of 12

\begin{tabular}{|c|c|c|c|c|c|}
\hline Study & Design & N Study Population & Outcome & $\begin{array}{l}\text { Follow up } \\
\text { (months) }\end{array}$ & Results \\
\hline $\begin{array}{l}\text { Fuchs et al. } \\
\text { [58]. }\end{array}$ & $\begin{array}{l}\text { Cross-sectional } \\
\text { study }\end{array}$ & $\begin{array}{l}2086 \text { HIV-infected men and } \\
1743 \text { HIV-infected women } \\
\text { Urban, community-based } \\
\text { facilities, multicenter, three } \\
\text { regions in Brazil }\end{array}$ & $\begin{array}{l}\text { 10-year risk of } \\
\text { coronary heart disease } \\
\text { using the FRS in HIV- } \\
\text { infected patients }\end{array}$ & NA & $\begin{array}{l}\text {-Prevalence of FRS } \geq 10 \text { was } 4.5 \% \text { in the South, } 4.2 \% \text { in the } \\
\text { Midwest, and } 3.9 \% \text { in the Northeast of Brazil. } \\
\text {-RR for CHD } 3.0(95 \% \mathrm{Cl} 2.1,4.2 ; p<0.001) \text { for HIV-infected } \\
\text { women compared to men }\end{array}$ \\
\hline $\begin{array}{l}\text { Lake et al. } \\
\text { [59]. }\end{array}$ & $\begin{array}{l}\text { Cross-sectional } \\
\text { study }\end{array}$ & $\begin{array}{l}408 \text { HIV-infected men and } 178 \\
\text { HIV-infected women } \\
\text { Urban, community-based, USA, } \\
\text { multiple cities }\end{array}$ & $\begin{array}{l}\text { Association between } \\
\text { regional adipose tissue } \\
\text { distribution and FRS }\end{array}$ & NA & $\begin{array}{l}\text {-Levels of CVD risk by FRS were higher in HIV-infected men vs } \\
\text { control men (median } 4.7 \% \text { vs. } 3.7 \% ; p=0.0002) \\
\text {-Levels of CVD risk by FRS were similar in HIV-infected and } \\
\text { control women }(1.1 \% \text { vs. } 1.2 \% ; p=0.91 \text { ) } \\
\text {-Prevalence of } 10 \text {-year CVD risk }>10 \% \text { was low in HIV-infected } \\
\text { and control women ( } 3 \% \text { vs. } 1 \% ; p=0.25) \text {. } \\
\text { - None of the women had } 10 \text {-year CVD risk }>20 \% \text {, regardless of } \\
\text { HIV status } \\
\text {-VAT showed a strong positive association with FRS in both HIV- } \\
\text { infected men and women }(r=0.34, p<0.0001)\end{array}$ \\
\hline $\begin{array}{l}\text { Kaplan et al. } \\
\text { [60]. }\end{array}$ & $\begin{array}{l}\text { Prospective, } \\
\text { observational } \\
\text { cohort }\end{array}$ & $\begin{array}{l}2386 \text { HIV-infected and } 1675 \\
\text { HIV-uninfected } \\
\text { Urban, community-based, USA, } \\
\text { multiple cities }\end{array}$ & $\begin{array}{l}\text { Prevalence of major } \\
\text { CVD risk factors and } \\
\text { FRS among HIV- } \\
\text { infected women and } \\
\text { men }\end{array}$ & 23 months & $\begin{array}{l}\text {-HIV-infected men: } 81 \% \text { had low predicted risk, } 2 \% \text { had } \\
\text { moderate, and } 17 \% \text { had high predicted risk based on FRS } \\
\text {-HIV-infected women: } 86 \% \text { had low predicted CHD risk, } 2 \% \text { had } \\
\text { moderate } 12 \% \text { had high risk based on FRS } \\
\text {-HIV-uninfected women: } 87 \% \text { had low predicted CHD risk } 1 \% \\
\text { had moderate and } 12 \% \text { had high risk based on FRS }\end{array}$ \\
\hline $\begin{array}{l}\text { Aboud et al. } \\
\text { [61]. }\end{array}$ & $\begin{array}{l}\text { Cross-sectional } \\
\text { study }\end{array}$ & $\begin{array}{l}756 \text { HIV-infected men and } 265 \\
\text { HIV-infected women } \\
\text { Urban, hospital-based, } \\
\text { international, England }\end{array}$ & $\begin{array}{l}\text { 10-year CVD risk as } \\
\text { determined by FRS in } \\
\text { a large HIV cohort }\end{array}$ & 15 months & $\begin{array}{l}\text { - Median FRS for CVD was } 4 \%,(0-56 \% / \text { decade }) \text { in men and } \\
1.4 \%(0-37 \% / \text { decade }) \text { in women } \\
\text {-CVD risk was }>20 \% \text { in } 6 \% \text { of men and } 1 \% \text { of women } \\
\text {-CVD risk was }>10 \% \text { in } 12 \% \text { of men and } 4 \% \text { of women }\end{array}$ \\
\hline $\begin{array}{l}\text { Law et al. } \\
\text { [16]. }\end{array}$ & $\begin{array}{l}\text { Prospective } \\
\text { observational } \\
\text { cohort }\end{array}$ & $\begin{array}{l}\text { 13,328 HIV-infected men and } \\
4272 \text { HIV-infected women } \\
\text { Community-based facilities, } \\
\text { international, } 20 \text { different } \\
\text { countries in Europe, North } \\
\text { America and Australia }\end{array}$ & 3 year risk of MI & 36 months & $\begin{array}{l}\text {-3-year risk of MI was higher in men than in women, } 0.92 \% \\
(0.47 \pm 1.42 \%) \text { vs. } 0.07 \%(0.05 \pm 0.19 \%) \\
\text {-Majority of Mls projected to occur in men: } 123(63 \pm 189) \\
\text { among } 13,328 \text { men vs. } 3(2 \pm 8) \text { among the } 4272 \text { women }\end{array}$ \\
\hline $\begin{array}{l}\text { Mangili et al. } \\
\text { [20]. }\end{array}$ & $\begin{array}{l}\text { Cross-sectional } \\
\text { study }\end{array}$ & $\begin{array}{l}234 \text { HIV-infected men and } 80 \\
\text { HIV-infected women } \\
\text { Urban, community-based, USA, } \\
\text { Mass }\end{array}$ & $\begin{array}{l}\text { Associations between } \\
\text { carotid and coronary } \\
\text { atherosclerosis and } \\
\text { metabolic syndrome }\end{array}$ & NA & $\begin{array}{l}\text {-Significantly more women than men had metabolic syndrome } \\
(p=0.018) \\
\text {-Mean common CIMT higher among those with metabolic } \\
\text { syndrome than among those without }(0.66 \mathrm{~mm} \text { vs. } 0.59 \mathrm{~mm} \text {; } \\
p=0.005) \\
\text {-Detectable CAC score was more common in those with } \\
\text { metabolic syndrome than without }(80.3 \% \text { vs. } 46.7 \% ; p<0.0001)\end{array}$ \\
\hline $\begin{array}{l}\text { Mangili et al. } \\
\text { [28]. }\end{array}$ & $\begin{array}{l}\text { Cross-sectional } \\
\text { study }\end{array}$ & $\begin{array}{l}242 \text { HIV-infected men and } \\
85 \text { HIV-infected women } \\
\text { Urban, community-based, USA, } \\
\text { Mass }\end{array}$ & $\begin{array}{l}\text { Associations between } \\
\text { CIMT and CAC } \\
\text { measurements and } \\
\text { cardiovascular risk } \\
\text { factors }\end{array}$ & NA & $\begin{array}{l}\text {-Mean common CIMT }( \pm \mathrm{SD}) \text { was } 0.62 \pm 0.2 \mathrm{~mm} \text { in men and } \\
0.59 \pm 0.2 \mathrm{~mm} \text { in women }(p=0.173) \\
\text {-Mean internal CIMT }( \pm \mathrm{SD}) \text { was } 0.76 \pm 0.5 \mathrm{~mm} \text { in men and } 0.66 \\
\pm 0.4 \mathrm{~mm} \text { in women }(p=0.109) \\
- \text { Women: age }(p=<0.001) \text { and BMI }(p=0.004) \text { correlated with } \\
\text { common CIMT; age }(p=<0.001) \text { correlated with internal CIMT; } \\
\text { age }(p=0.004) \text { and glucose }(p=0.009) \text { correlated with CAC score }\end{array}$ \\
\hline $\begin{array}{l}\text { Seaberg et } \\
\text { al. [62]. }\end{array}$ & $\begin{array}{l}\text { Cross-sectional } \\
\text { study }\end{array}$ & $\begin{array}{l}924 \text { HIV-infected men from } \\
\text { MACS study and } 924 \text { HIV- } \\
\text { infected women from WIHS } \\
\text { Study } \\
\text { Urban, community and hospital- } \\
\text { based, USA, multiple cities }\end{array}$ & $\begin{array}{l}\text { Associations between } \\
\text { HIV infection and } \\
\text { HAART use and } \\
\text { arterial stiffness using } \\
\text { measurements of } \\
\text { CIMT }\end{array}$ & NA & $\begin{array}{l}\text {-Median carotid distensibility was similar in MACS vs. WIHS } \\
-\mathrm{CD} 4<200 \text { did not differ significantly between MACS (PD -6.9) } \\
\text { and WIHS (PD }-9.2, p=0.46 \text { ) } \\
\text { - HIV infection was associated with lower distensibility (PD -4.3, } \\
95 \% \mathrm{Cl}-7.40,-1.10 \text { ), with the effect greater in MACS (PD -5.5) } \\
\text { compared to WIHS (PD -1.9) } \\
\text {-Distensibility was significantly lower among those taking HAART } \\
\text { in the MACS (PD }-4.2,95 \% \mathrm{Cl}-7.00,-1.40 \text { ), but not in the WIHS }\end{array}$ \\
\hline $\begin{array}{l}\text { Karim et al. } \\
\text { [63]. }\end{array}$ & $\begin{array}{l}\text { Nested Case- } \\
\text { control study }\end{array}$ & $\begin{array}{l}414 \text { HIV-infected women and } \\
170 \text { HIV-uninfected women (sex } \\
\text { and hormone data). } 771 \text { HIV- } \\
\text { infected and } 323 \text { HIV-uninfected } \\
\text { women (androgen analyses) } \\
\text { Urban, Community-based, USA, } \\
\text { multiple cities }\end{array}$ & $\begin{array}{l}\text { Associations between } \\
\text { sex hormones, } \\
\text { gonadotropin, a marker } \\
\text { of ovarian reserve } \\
\text { (inhibin-B), and SHBG } \\
\text { and CIMT }\end{array}$ & NA & $\begin{array}{l}\text {-CIMT was similar between HIV- and HIV }+ \text { women } 0.722( \pm \\
0.100) \text { vs } 0.715( \pm 0.106) p=0.52 \text { (sex hormone data cohort) and } \\
0.714( \pm 0.099) \text { vs } 0.718( \pm 0.109) p=0.59 \text { (androgen cohort) } \\
\text {-Serum E2, T, and DHEAS concentrations were significantly } \\
\text { lower, whereas SHBG was higher in HIV-infected vs HIV- } \\
\text { uninfected women) and }>350(0.056, p=0.001)\end{array}$ \\
\hline $\begin{array}{l}\text { Parrinello et } \\
\text { al. [64]. }\end{array}$ & Cross-sectional & $\begin{array}{l}601 \text { HIV-infected women and } \\
90 \text { HIV-uninfected women } \\
\text { Urban, community-based, } \\
\text { USA, multiple cities }\end{array}$ & $\begin{array}{l}\text { Association between } \\
\text { CMV IgG titers and } \\
\text { subclinical vascular } \\
\text { disease (carotid } \\
\text { ultrasound) }\end{array}$ & NA & $\begin{array}{l}\text {-HIV-infected women had higher serum CMV IgG levels } \\
\text { compared with uninfected women: mean, } 25.4 \text { IU/mL; SD, } 9.9 \text { vs. } \\
19.4 \text { IU/mL SD } 9.2 p<0.01 \\
\text {-In HIV-infected women, CMV IgG was not associated with either } \\
\text { CIMT ( } r=0.01 ; p=0.86) \text { or carotid artery lesions prevalence RL } \\
1.12(95 \% \mathrm{Cl} 0.87,1.49 ; p=0.38) \\
\text {-In HIV-infected women CMV IgG levels were associated } \\
\text { with carotid artery distensibility and increased Young's elastic } \\
\text { modulus (both } p<0.01)\end{array}$ \\
\hline
\end{tabular}




\begin{tabular}{|c|c|c|c|c|c|}
\hline Study & Design & N Study Population & Outcome & $\begin{array}{l}\text { Follow up } \\
\text { (months) }\end{array}$ & Results \\
\hline $\begin{array}{l}\text { Parrinello et } \\
\text { al. [19]. }\end{array}$ & $\begin{array}{l}\text { Nested Case- } \\
\text { control study }\end{array}$ & $\begin{array}{l}1305 \text { HIV-infected women and } \\
522 \text { HIV-uninfected women - } \\
\text { Urban, community-based, } \\
\text { USA, multiple cities }\end{array}$ & $\begin{array}{l}\text { Association between } \\
\text { serum lipids and CIMT }\end{array}$ & NA & $\begin{array}{l}\text {-In HIV-uninfected women, higher TC }(2.17 ; \mathrm{Cl} 0.07,4.27 \text {; } \\
p=0.04) \text {, LDL-c }(3.46 ; 95 \% \mathrm{CI} 1.02,5.90 ; p=0.01) \text {, and non- } \\
\text { HDL-c (2.40; } 95 \% \mathrm{CI} 0.36,4.44 ; p=0.02) \text { were associated with } \\
\text { increased CIMT } \\
\text {-In HIV-infected women on ART, LDL-C }(2.27 ; 95 \% \mathrm{CI} 0.19,4.35 \text {, } \\
p=0.03) \text { and non-HDL-c }(1.66 ; 95 \% \mathrm{CI} 0.03,3.36 ; p=0.05) \text { were } \\
\text { associated with increased CIMT } \\
\text {-In HIV-infected women not on ART, no associations were seen } \\
\text { between lipids and CIMT }\end{array}$ \\
\hline $\begin{array}{l}\text { Lazar et al. } \\
\text { [23]. }\end{array}$ & $\begin{array}{l}\text { Prospective } \\
\text { observational } \\
\text { cohort }\end{array}$ & $\begin{array}{l}276 \text { HIV-infected women and } \\
67 \text { HIV-uninfected women } \\
\text { Community-based, international, } \\
\text { Rwanda }\end{array}$ & $\begin{array}{l}\text { Comparison of } \\
\text { arterial stiffness in } \\
\text { HIV-infected vs. HIV- } \\
\text { uninfected women }\end{array}$ & 6 months & $\begin{array}{l}\text {-Mean C-AI was significantly lower in HIV-infected vs HIV- } \\
\text { uninfected women }(20.3 \pm 12.0 \text { vs. } 25.5 \pm 12.1 ; p=0.002) \\
\text {-P-AI }(74.6 \pm 18.8 \text { vs. } 83.7 \pm 20.0 ; p<0.001) \text { was lower in the } \\
\text { HIV-infected group } \\
\text {-C-PP was similar between the groups }(28.1 \pm 8.0 \text { vs. } 27.4 \pm 9.0 \text {; } \\
p=0.54) \\
\text {-In HIV-infected women, CD4 count was not correlated with } \\
\text { C-Al (Rho }=-0.01, p=0.84) \text {, central PP (Rho }=0.09, p=0.16) \text {, or } \\
\text { peripheral } \mathrm{Al}(\mathrm{Rho}=-0.01, p=0.83)\end{array}$ \\
\hline $\begin{array}{l}\text { Sharma et al. } \\
\text { [29]. }\end{array}$ & $\begin{array}{l}\text { Cross-sectional } \\
\text { study }\end{array}$ & $\begin{array}{l}238 \text { HIV-infected women and } 97 \\
\text { HIV-uninfected women } \\
\text { Urban, community-based, USA, } \\
\text { multiple cities }\end{array}$ & $\begin{array}{l}\text { Prevalence of and risk } \\
\text { factors for PAD using } \\
\text { ABI }\end{array}$ & NA & $\begin{array}{l}\text {-Overall prevalence of low } \mathrm{ABI}(<0.9) \text { was } 0.9 \% \text { and high } \mathrm{ABI} \\
(>1.40) \text { was } 6.9 \% \text { [ } 95 \% \mathrm{Cl} 4.4,10.2 \% ; \mathrm{n}=23] \\
\text {-The prevalence rates of high } \mathrm{ABI} \text { among } \mathrm{HIV}+\text { vs } \mathrm{HIV} \text { - subjects } \\
\text { were similar }(7.2 \% \text { vs. } 6.3 \% ; p=0.84) \\
\text {-The prevalence of low } \mathrm{ABI} \text { was too low to allow analyses }\end{array}$ \\
\hline
\end{tabular}

Studies with N>100 subjects were included. FRS: Framingham Risk Score; NA: Not applicable; RR: Relative Risk; Cl: Confidence Interval; CHD: Coronary Heart Disease; MI: Myocardial Infarction; HAART: Highly Active Antiretroviral Therapy; CIMT: Carotid Intimal Medial Thickness; MACS: Multicenter AIDS Cohort Study; WIHS: Women's Interagency HIV Cohort Study; CD: Cluster of differentiation; PD: Percent Difference; E2: estradiol; T: testosterone; DHEAS: Dehydroepiandrosterone Sulphate; SHBG: Sex Hormone Binding Globulin; C-Al: Central Augmentation Index; P-Al: Peripheral Augmentation Index; C-PP: Central Pulse Pressure; PAD: Peripheral Arterial Disease; ABI: Ankle-Brachial Index; Mass: Massachusetts; CAC: Coronary Artery Calcium; SD: Standard Deviation; CVD: Cardiovascular Disease; VAT: Visceral Adipose Tissue

Table 2: Studies assessing surrogate measures of cardiovascular disease.

mortality in the general population [21]. There is limited data on PWV in HIV- infected women, and only two studies reported on gender in their results. Eira et al. noted that there was a significant trend towards higher values of aortic PWV in HIV-infected women with diabetes or on ART among 18 HIV-infected women [22]. A Rwandan study of 276 HIV-infected women found no significant differences in measures of radial arterial wave reflection between HIV-infected and HIVuninfected women after adjustment for potential confounders and age [23]. More studies with larger numbers need to be conducted in order to obtain more conclusive results on the association between HIV infection and PWV in women.

Computed tomography coronary angiography (CTA): There were three studies that evaluated CTA in HIV-infected women. Computed tomography coronary angiography has been used to evaluate coronary atherosclerosis in the general population, and its use has been promoted by recent studies $[24,25]$. There is a growing body of literature using the computed tomography coronary angiography (CTA) to assess subclinical CVD in HIV-infected individuals. Fitch et al. evaluated atherosclerotic plaque morphology among HIV-infected and HIV-uninfected women. The presence of coronary plaques was similar in both groups, but HIV-infected females had a significantly higher prevalence of non-calcified coronary artery plaques $(35 \%$ vs $12 \%$ in female control subjects; $\mathrm{p}=0.04$ ) which remained significant even after adjustment for CV risk factors such as age, race, FRS, smoking status, levels of triglycerides (TGs), HDL-c and LDL-c, and BMI. The percentage of coronary segments with non-calcified plaques was significantly higher in HIV-infected women (median $75 \%$ IQR 63\%-100\%) compared to HIV-infected men (median 50\% IQR 3\%$100 \% ; \mathrm{p}<0.05$,) [26] which is important because non-calcified plaques are considered vulnerable and more susceptible to rupture leading to acute coronary syndromes [27]. Coronary artery calcium scores (CAC) have been found to be higher in HIV-infected patients with metabolic syndrome compared to those without metabolic syndrome [20]. The same study showed that HIV-infected women had higher rates of metabolic syndrome compared with HIV-infected men. Conversely, another study found that HIV-uninfected women had statistically significant higher percentage of CAC $>100(p=0.02)$ compared to HIV-infected women [26]. Other studies did not demonstrate gender differences in CAC $[20,28]$. From the limited studies of CTA in HIVinfected women, there is a suggestion that certain plaque morphologies may be greater in HIV-infected women compared to controls, but larger studies need to be performed to establish firmer conclusions.

Ankle-brachial index (ABI): There is limited data on ABI in HIVinfected women, and only one study reported on gender in their results. Sharma et al evaluated ABI in 238 HIV-infected women and 97 HIVuninfected women. The presence of low ABI was too few for analysis $(n=3,0.9 \%)$, but it was noted that the presence of high ABI was more frequent than expected $(n=23,6.9)$ with an unclear clinical significance [29]. More studies with larger numbers need to be conducted to further evaluate the association between ABI and HIV infection in women and to develop meaningful clinically significant cut-off values.

\section{Risk factors and metabolic indices}

Several studies have evaluated traditional CHD risk factors, metabolic indices, and markers of inflammation in HIV infected women. Table 3 lists selected studies that reported on traditional CHD risk factors, markers of inflammation, and HAART. Table 4 lists selected studies that reported on metabolic indices that contribute to CHD risk.

\section{Traditional risk factors}

Studies report differing impact of traditional CV risk factors on CHD risk. There were six studies that evaluated traditional risk factors in HIV-infected women. Triant et al. noted increased rates of hypertension, diabetes, and dyslipidemia stratified by gender in HIVinfected patients compared to HIV-uninfected patients [9]. Womack et al. observed an increased prevalence of dyslipidemia and smoking 
Citation: Adekunle R, Bagchi S (2016) Review of Cardiovascular Disease in HIV-Infected Women. J AIDS Clin Res 7: 557. doi:10.4172/21556113.1000557

Page 6 of 12

\begin{tabular}{|c|c|c|c|c|c|}
\hline Study & Design & N Study Population & Outcome & $\begin{array}{l}\text { Follow up } \\
\text { (months) }\end{array}$ & Results \\
\hline $\begin{array}{l}\text { Kroll et al. } \\
{[65] .}\end{array}$ & $\begin{array}{l}\text { Cross- } \\
\text { sectional } \\
\text { study }\end{array}$ & $\begin{array}{l}208 \text { HIV-infected men } \\
\text { and } 146 \text { HIV-infected } \\
\text { women } \\
\text { Community-based, } \\
\text { international, Brazil }\end{array}$ & $\begin{array}{l}\text { Prevalence of obesity } \\
\text { and cardiovascular } \\
\text { risk in HIVIAIDS } \\
\text { outpatients according } \\
\text { to sex, antiretroviral } \\
\text { therapy and other } \\
\text { variables }\end{array}$ & NA & $\begin{array}{l}\text {-Women were more frequently obese compared to men }(14.1 \% \text { vs. } 4.4 \%) \\
\text {-Women had a higher odds of CVR than men (OR=6.97; Cl } 95 \% \text {, } \\
4.16<O R<11.76) \\
\text {-Very high CVR was more prevalent in women than men }(51.4 \% \text { vs. } 9.4 \% \text {; } \\
p<0.001) \\
\text {-No statistically significant differences noted in associations between nutritional } \\
\text { status, CD4 counts, and VL and ART type ( } p \text { value not provided) between men } \\
\text { and women }\end{array}$ \\
\hline $\begin{array}{l}\text { Mateen et } \\
\text { al. [66]. }\end{array}$ & $\begin{array}{l}\text { Prospective, } \\
\text { observational } \\
\text { cohort }\end{array}$ & $\begin{array}{l}1841 \text { HIV-infected } \\
\text { men and } 3722 \text { HIV- } \\
\text { infected women } \\
\text { Urban, community- } \\
\text { based, secondary care } \\
\text { center, international, } \\
\text { Uganda }\end{array}$ & $\begin{array}{l}\text { Hypertension and risk } \\
\text { of CVD }\end{array}$ & NA & $\begin{array}{l}\text {-Men were more likely to carry a diagnosis of HTN prior to the age of } 40 \\
(p<0.0001) \\
-83 \% \text { women were in the very low risk FRS category } \\
-20 \% \text { of men were in } \geq 10 \% \text { or FRS category }\end{array}$ \\
\hline $\begin{array}{l}\text { Kaplan et } \\
\text { al. [37]. }\end{array}$ & $\begin{array}{l}\text { Prospective, } \\
\text { observational } \\
\text { cohort }\end{array}$ & $\begin{array}{l}127 \text { HIV-infected } \\
\text { women and } 127 \text { HIV- } \\
\text { uninfected women } \\
\text { Urban, community- } \\
\text { based, USA, multiple } \\
\text { cities }\end{array}$ & $\begin{array}{l}\text { Associations between } \\
\text { levels of markers } \\
\text { of inflammation pre } \\
\text { and post HAART } \\
\text { and subclinical } \\
\text { atherosclerosis } \\
\text { (CIMT) }\end{array}$ & 29 months & $\begin{array}{l}\text {-Both pre- and post-HAART: higher HIV RNA was associated with higher } \\
\text { levels of TNF-alpha }(p<0.01), \text { IL-2 receptor }(p<0.0001), \mathrm{IL}-10(p<0.00), \mathrm{MCP}-1 \\
(p<0.001) \text { and D-dimer }(p<0.04) \\
\text {-Prior to HAART initiation, biomarker levels were not associated with CIMT } \\
\text {-After HAART: } \\
\text {-TNF and IL-2 remained elevated compared to HIV-uninfected women } \\
(p<0.0001 \text { and } p<0.01 \text { respectively). } \\
\text {-CIMT was associated with higher levels of soluble IL-2 ( } p=0.02), \mathrm{IL}-6(p=0.05) \text {, } \\
\text { and D-Dimer }(p=0.03) \text { in HIV+ women }\end{array}$ \\
\hline $\begin{array}{l}\text { Shaked et } \\
\text { al. [36]. }\end{array}$ & $\begin{array}{l}\text { Cross- } \\
\text { sectional } \\
\text { study }\end{array}$ & $\begin{array}{l}264 \text { women } \\
\text { participants } \\
\text { Urban, community- } \\
\text { based, USA, multiple } \\
\text { cities }\end{array}$ & $\begin{array}{l}\text { Association between } \\
\text { plasma markers } \\
\text { of macrophage } \\
\text { inflammation } \\
\text { and activation } \\
\text { and subclinical } \\
\text { atherosclerosis } \\
\text { (carotid ultrasound) }\end{array}$ & NA & $\begin{array}{l}-4 \text { groups: } 66 \mathrm{HIV}-/ \mathrm{HCV}-, 66 \mathrm{HIV}+/ \mathrm{HCV}-, 66 \mathrm{HIV}-/ \mathrm{HCV}+, 66 \mathrm{HIV}+/ \mathrm{HCV}+ \\
-\mathrm{HIV}+/ \mathrm{HCV}+\text { had the highest mean levels of sCD163 and sCD14 }(11.25 \mathrm{ng} / \mathrm{mL} \\
\text { and } 1,649 \mathrm{ng} / \mathrm{mL} \text {, respectively) } \\
-\mathrm{HIV}-/ \mathrm{HCV} \text { - had the lowest mean }(10.07 \mathrm{ng} / \mathrm{mL} \text { and } 1,179 \mathrm{ng} / \mathrm{mL} \text {, respectively) } \\
\text {-Gal-3BP was higher in HCV+ women than in HCV- women (mean } 12.4 \mu \mathrm{g} / \mathrm{mL} \\
\text { vs. } 8.6 \mu \mathrm{g} / \mathrm{mL} ; p<0.01) \text {, but did not differ based on HIV status (mean } 10.3 \mu \mathrm{g} / \mathrm{mL} \\
\text { vs. } 10.7 \mu \mathrm{g} / \mathrm{mL} ; p=0.34) \\
\text {-Levels of gal-3BP }(\mathrm{OR}=1.48 ; p=0.04), \mathrm{sCD} 163(\mathrm{OR}=1.85 ; p=0.005) \text {, and } \\
\text { sCD14 (OR=1.4; } p=0.03) \text { were associated with an increased odds of having a } \\
\text { carotid artery lesion. } \\
\text {-Levels of Gal3BP }(1.44 ; p<0.001) \text { and sCD14 }(-1.11 ; p=0.03 \text { ) were associated } \\
\text { with distensibility }\end{array}$ \\
\hline $\begin{array}{l}\text { Kaplan et } \\
\text { al. [67]. }\end{array}$ & $\begin{array}{l}\text { Nested Case- } \\
\text { control study }\end{array}$ & $\begin{array}{l}115 \text { HIV-infected } \\
\text { women and } 43 \text { HIV- } \\
\text { uninfected women } \\
\text { Urban, community- } \\
\text { based, USA, multiple } \\
\text { cities }\end{array}$ & $\begin{array}{l}\text { Associations between } \\
\text { HIV infection and } \\
\text { plasma markers of } \\
\text { inflammation, immune } \\
\text { activation, and } \\
\text { immunosenescence } \\
\text { and vascular disease } \\
\text { (carotid ultrasound) }\end{array}$ & 30 month & $\begin{array}{l}- \text { HIV-infected women had higher levels of CD4+ and CD8+ T cell activation } \\
\text { (both } p<0.01) \text { than uninfected women. } \\
\text {-Percentage of CD28- CD57+ was increased among the HIV-infected women } \\
(p<0.01) \text { compared to uninfected women } \\
\text {-HIV-infected women with carotid lesions had a higher percentage of both CD4+ } \\
\text { and CD8+ CD38+ HLA-DR+ than HIV-infected women without carotid lesions } \\
(p=0.02) \\
\text {-CIMT was not associated with T cell activation or senescence markers in HIV- } \\
\text { infected women }\end{array}$ \\
\hline $\begin{array}{l}\text { Shikuma } \\
\text { et al. [47]. }\end{array}$ & $\begin{array}{l}\text { Retrospective } \\
\text { study }\end{array}$ & $\begin{array}{l}145 \text { HIV-infected men } \\
\text { and } 51 \text { HIV-infected } \\
\text { women } \\
\text { Urban, multicenter, } \\
\text { USA }\end{array}$ & $\begin{array}{l}\text { Effect of virologically } \\
\text { suppressive EFV- } \\
\text { based ART on hsCRP } \\
\text { levels with particular } \\
\text { attention to the effect } \\
\text { of gender and ABC } \\
\text { use }\end{array}$ & 22 months & $\begin{array}{l}\text {-At week } 0 \text {, hsCRP did not differ by gender between men and women [median } \\
(\mathrm{Q} 1, \mathrm{Q} 3) \text { : men } 1.4 \mathrm{mg} / \text { liter }(0.7,3.9) \text { versus women } 2.3 \mathrm{mg} / \mathrm{liter}(0.9,5.3) \\
p=0.13 \\
\text {-At week } 96, \text { women had higher levels of hsCRP (median } 6 \mathrm{mg} / \mathrm{liter} ; \mathrm{Q} 1, \mathrm{Q} 3 \\
1.8,13.8) \text { compared to men (median } 1.6 \mathrm{mg} / \mathrm{liter} \text {; } \mathrm{Q} 1, \mathrm{Q} 3,0.9,4.2 ; p<0.001) \\
\text {-There was no difference in hsCRP levels when comparing ABC based vs. EFV- } \\
\text { based use at week } 0(p=0.95) \text { or at week } 96(p=0.38) \\
\text {-Changes in hsCRP did not correlate with changes in insulin resistance or with } \\
\text { changes in fasting lipids (all } p>0.3)\end{array}$ \\
\hline $\begin{array}{l}\text { Tien et al. } \\
{[46] .}\end{array}$ & $\begin{array}{l}\text { Cross- } \\
\text { sectional } \\
\text { study }\end{array}$ & $\begin{array}{l}716 \text { HIV-infected } \\
\text { women and } 361 \text { HIV- } \\
\text { uninfected women } \\
\text { Urban, community- } \\
\text { based, USA, multiple } \\
\text { cities }\end{array}$ & $\begin{array}{l}\text { Associations between } \\
\text { HIV and HAART } \\
\text { use and LDL-p and } \\
\text { HDL-p in HIV-infected } \\
\text { women compared to } \\
\text { uninfected women }\end{array}$ & NA & $\begin{array}{l}\text {-75th, 90th, and 95th percentiles of small LDL- } p \text { in women on HAART were } \\
\text { higher than in HIV-infected and HAART Naïve (CI or } p \text { values not provided) } \\
\text { women } \\
\text {-After further adjustment for TG and HDL-C, the association between HAART } \\
\text { and small LDL-p was no longer significant } \\
\text {-HIV-uninfected women had higher total and small HDL-p than HIV-infected } \\
\text { women at each of the percentiles. This remained significant after adjustment for } \\
\text { TG and HDL-C }\end{array}$ \\
\hline $\begin{array}{l}\text { Estrada et } \\
\text { al. [44]. }\end{array}$ & $\begin{array}{l}\text { Cross- } \\
\text { sectional } \\
\text { study }\end{array}$ & $\begin{array}{l}922 \text { HIV-infected } \\
\text { women } \\
\text { Urban, multicenter, } \\
\text { international, pain }\end{array}$ & $\begin{array}{l}\text { Lipid profile in a large } \\
\text { cohort of HIV-infected } \\
\text { women on ART }\end{array}$ & NA & $\begin{array}{l}\text {-Significantly higher HDL values were observed in NNRTI-treated patients } \\
\text { - NRTI vs NNRTI }(p=0.001) \text { and PI vs NNRTI }(p<0.001) \\
\text {-Patients on PI treatment had higher TC/HDL ratio than those on NNRTI } \\
(p<0.001) \text {. } \\
\text { - In a multivariate analysis, the following factors were independently associated } \\
\text { with TC/HDL ratio: age }(p=0.045), \text { TG levels }(p=0.001) \text {, and HCV co-infection } \\
(p=0.002)\end{array}$ \\
\hline
\end{tabular}


Citation: Adekunle R, Bagchi S (2016) Review of Cardiovascular Disease in HIV-Infected Women. J AIDS Clin Res 7: 557. doi:10.4172/21556113.1000557

Page 7 of 12

\begin{tabular}{|l|l|l|l|l|l|}
\hline Study & Design & N Study Population & Outcome & $\begin{array}{l}\text { Follow up } \\
\text { (months) }\end{array}$ & \multicolumn{1}{|c|}{ Results } \\
\hline $\begin{array}{l}\text { Shaffer et } \\
\text { al. [45]. }\end{array}$ & $\begin{array}{l}\text { Two parallel, } \\
\text { randomized, } \\
\text { open-label } \\
\text { trials }\end{array}$ & $\begin{array}{l}741 \text { women } \\
\text { randomized } \\
\text { Multicenter, } \\
\text { international; } 7 \\
\text { countries in sub- } \\
\text { Saharan Africa }\end{array}$ & $\begin{array}{l}\text { CVD risk factors } \\
\text { following initiation of } \\
\text { NNRTI vs. Pl-based } \\
\text { ART }\end{array}$ & $\begin{array}{l}33.1 \text { months } \\
\text { SRTior to ART, both NVP and LPV/r groups had similar mean lipid levels (TC, } \\
\text { HDL, non-HDL, LDL, and TG) } \\
\text {-The following are the changes at 144 weeks } \\
\text {-TC (adjusted } p=0.090), \text { LDL (adjusted } p=0.118), \text { and non-HDL was higher in } \\
\text { NVP group compared to LPV/r group } \\
\text {-HDL increase was less and TG decreased (adjusted } p=0.001) \text { in NVP group } \\
\text { (adjusted } p=0.002)\end{array}$ \\
\hline
\end{tabular}

Studies of N>100 subjects were included. HAART: Highly Active Antiretroviral Therapy; CIMT: Carotid Intimal Medial Thickness; TNF- $\alpha$ : Tumor Necrosis Factor Alpha; IL: Interleukin; MCP - 1: Monocyte Chemoattractant Protein - 1; CVD: Cardiovascular Disease; FRS: Framingham Risk Score; CHD: Coronary Heart Disease; NA: Not Applicable; HCV: Hepatitis C Virus; CD: Cluster of differentiation; Gal-3BP: Galectin-3 binding protein; CVR: Cardiovascular Risk; OR: Odds Ratio; CI: Confidence Interval;

VL: Viral Load; ART: Antiretroviral Therapy; LDL-p: Low-Density Lipoprotein Cholesterol Particle; HDL-p: High-Density Lipoprotein Particle; TG: Triglycerides; HDL - C: High Density Lipoprotein Cholesterol; EFV: Efavirenz; hsCRP: High Sensitivity C-Reactive Protein; ABC: Abacavir; NNRTI: Non-nucleoside Reverse Transcriptase Inhibitors; NRTI: Nucleoside Reverse Transcriptase Inhibitors; PI: Protease Inhibitor; TC: Total Cholesterol; NVP: Nevirapine; LPV/r: Lopinavir/Ritonavir; HTN: Hypertension; HLA Human Leukocyte Antigen; RL: Ratio Lesions; CMV: Cytomegalovirus; SHBG: Sex Hormone Binding Globulin; T: Testosterone ; E2: Total Estradiol

Table 3: Studies assessing Traditional Cardiovascular Risk Factors, Markers of Inflammation, HAART.

\begin{tabular}{|c|c|c|c|c|c|}
\hline Study & Design & N Study Population & Outcome & $\begin{array}{l}\text { Follow up } \\
\text { (months) }\end{array}$ & Results \\
\hline $\begin{array}{l}\text { Mangili et al. } \\
\text { [20]. }\end{array}$ & $\begin{array}{l}\text { Cross- } \\
\text { sectional study }\end{array}$ & $\begin{array}{l}234 \text { HIV-infected men } \\
\text { and } 80 \text { HIV-infected } \\
\text { women } \\
\text { Urban, community- } \\
\text { based, USA, Mass }\end{array}$ & $\begin{array}{l}\text { Associations between } \\
\text { carotid and coronary } \\
\text { atherosclerosis and } \\
\text { MS }\end{array}$ & NA & $\begin{array}{l}\text {-Significantly more women than men had MS }(p=0.018) \\
\text {-Mean common CIMT higher among those with MS than among those without } \\
(0.66 \mathrm{~mm} \text { vs. } 0.59 \mathrm{~mm} ; p=0.005) \\
\text {-Detectable CAC score was more common in both HIV-infected men and women } \\
\text { with MS than without }(80.3 \% \text { vs. } 46.7 \% ; p<0.0001)\end{array}$ \\
\hline $\begin{array}{l}\text { Janiszewski et } \\
\text { al. [14]. }\end{array}$ & $\begin{array}{l}\text { Cross- } \\
\text { sectional study }\end{array}$ & $\begin{array}{l}1481 \text { HIV-infected } \\
\text { men and } 841 \text { HIV- } \\
\text { infected women } \\
\text { Urban, community- } \\
\text { based, Italy }\end{array}$ & $\begin{array}{l}\text { Associations between } \\
\text { WC and TG levels } \\
\text { and severity of } \\
\text { lipodystrophy and } \\
\text { CVR }\end{array}$ & NA & $\begin{array}{l}\text {-In the women, VAT was highest among the high WC groups }(p<0.05) \text {, but not } \\
\text { different between the low TG/high WC and high TG/high WC groups (139.2 } \pm \\
146.7 \mathrm{~cm}^{2} \text { and } 150.0 \pm 97.9 \mathrm{~cm}^{2} \text {, respectively) } \\
\text {-CVR was greatest among men in the high TG/high WC group ( } p<0.05) \\
\text {-Prevalence of MS was significantly higher in the high TG/high WC women than } \\
\text { in any other group ( } 55.7 \% \text { vs. range of } 2.1 \text { to } 25.8 \% ; p<0.05 \text { for all comparisons) }\end{array}$ \\
\hline $\begin{array}{l}\text { Pullinger et al. } \\
\text { [67]. }\end{array}$ & $\begin{array}{l}\text { Cross- } \\
\text { sectional study }\end{array}$ & $\begin{array}{l}217 \text { HIV-infected men } \\
\text { and } 79 \text { HIV-infected } \\
\text { women } \\
\text { Urban, community- } \\
\text { based, USA, San } \\
\text { Francisco }\end{array}$ & $\begin{array}{l}\text { Parameters that } \\
\text { contribute to MS and } \\
\text { estimating the } 10 \text {-year } \\
\text { risk of CHD }\end{array}$ & NA & $\begin{array}{l}\text { - The prevalence of MS was similar in HIV-infected women and men }(35.3 \% \text { vs. } \\
28.1 \% ; p=0.0266) \\
\text {-High WC was associated with MS more in women than in men }(p<0.001) \\
\text {-Elevated TG was associated with MS more in men than in women }(p<0.01) \\
-10 \text {-year FRS were higher in men }(7.6 \pm 5.4 \%) \text { compared to women }(4.6 \pm 5.4 \% \text {; } \\
p<0.001) \text {. } \\
\text { - FRS for those with MS was } 10.5 \pm 7.6 \text { (74 SD) vs. } 5.6 \pm 41 \text { (183 SD) in those } \\
\text { without MS; } p<0.001\end{array}$ \\
\hline $\begin{array}{l}\text { Baum et al. } \\
\text { [32]. }\end{array}$ & $\begin{array}{l}\text { Cross- } \\
\text { sectional study }\end{array}$ & $\begin{array}{l}87 \text { HIV-infected men } \\
\text { and } 31 \text { HIV-infected } \\
\text { women, all drug users } \\
\text { Urban, community- } \\
\text { based, USA, Miami }\end{array}$ & $\begin{array}{l}\text { 10-year CHD risk } \\
\text { and the prevalence } \\
\text { of MS with further } \\
\text { stratification of those } \\
\text { who are on HAART } \\
\text { with or without Pls }\end{array}$ & NA & $\begin{array}{l}-10-y e a r \text { CHD risk was significantly higher in men }(5.9 \pm 6.1 ; p<0.001) \text { than in } \\
\text { women }(1.7 \pm 2.4) \\
- \text { The rate of MS was significantly higher in women }(29 \% \text { vs } 10.3 \% ; p=0.013) \\
\text { compared to men } \\
\text {-The factors associated with higher prevalence of MS among women: higher } \\
\text { rate of abdominal obesity }(54.8 \% \text { in women vs. } 8.1 \% \text { in men; } p<0.001) \text { and lower } \\
\text { HDL }(61.3 \% \text { in women vs. } 40 \% \text { in men; } p=0.042) \\
- \text { HAART with or without PI was not associated with an increased risk of CVD } \\
\text { (data not provided) }\end{array}$ \\
\hline $\begin{array}{l}\text { Sobieszczyk } \\
\text { et al. [31]. }\end{array}$ & $\begin{array}{l}\text { Prospective, } \\
\text { observational } \\
\text { cohort }\end{array}$ & $\begin{array}{l}1725 \text { HIV-infected } \\
\text { women and } 668 \text { HIV- } \\
\text { uninfected women } \\
\text { Urban, community- } \\
\text { based, USA, multiple } \\
\text { cities }\end{array}$ & $\begin{array}{l}\text { Associations between } \\
\text { prevalence of MS } \\
\text { and HIV infection, } \\
\text { antiretroviral therapies, } \\
\text { and sociodemographic } \\
\text { factors }\end{array}$ & 48 months & $\begin{array}{l}\text {-Prevalence of MS was significantly higher in HIV-infected women than } \\
\text { uninfected women ( } 33 \% \text { vs } 22 \% ; p<0.0001) \\
\text {-HIV status was associated with MS in multivariate analyses (OR=1.79; } \\
p<0.0001) \\
\text {-Factors associated with higher prevalence of MS in HIV-infected women } \\
\text { included: white race }(\mathrm{OR}=1.91 ; p<0.001) \text {, older age }(\mathrm{OR}=1.38 \text { per } 5 \text { year } \\
\text { increase; } p<0.0001) \text {, higher } \mathrm{BMI}(\mathrm{OR}=2.05 \text { for } \mathrm{BMl} 26-30 \text { and } \mathrm{OR}=5.72 \text { for } \mathrm{BMI} \\
.30 \mathrm{~kg} / \mathrm{m} 2 \mathrm{vs} \mathrm{BMI} 21-25 ; p<0.0001) \text {, current smoking }(\mathrm{OR}=1.31 ; p<0.014), \mathrm{HIV}-1 \\
\text { RNA } 50,000(\mathrm{OR}=1.36 ; p<0.019 \text {, and use of d4T (OR=1.28; } p<0.009)\end{array}$ \\
\hline $\begin{array}{l}\text { Mulligan et al. } \\
\text { [30]. }\end{array}$ & $\begin{array}{l}\text { Cross- } \\
\text { sectional study }\end{array}$ & $\begin{array}{l}173 \text { HIV-infected } \\
\text { female adolescents } \\
\text { and } 65 \text { HIV-uninfected } \\
\text { female adolescents } \\
\text { Urban, community and } \\
\text { hospital based, multiple } \\
\text { sites }\end{array}$ & $\begin{array}{l}\text { Associations } \\
\text { between prevalence } \\
\text { of abnormalities in } \\
\text { glucose metabolism, } \\
\text { lipids, and body } \\
\text { composition and } \\
\text { different classes of } \\
\text { ART regimens. }\end{array}$ & NA & $\begin{array}{l}\text {-Average BMI, height, and weight did not differ among groups }(p=0.96) \\
- \text { TGs were higher in all HIV }(+) \text { groups compared with HIV }(-)(p=0.008) \text { and } \\
\text { significantly higher in NNRTI than ART-naïve }(p<0.0001) \\
- \text { TC was higher in NNRTI and PI groups compared to both HIV(-) and ART-naïve } \\
(p=0.002) \\
\text {-Fasting and 2-h glucose, insulin, pro-insulin, C-peptide, and HOMA-IR } \\
\text { decreased with BMI (all } p \text { - values }<0.01)\end{array}$ \\
\hline $\begin{array}{l}\text { Freitas et al. } \\
\text { [69]. }\end{array}$ & $\begin{array}{l}\text { Cross- } \\
\text { sectional study }\end{array}$ & $\begin{array}{l}239 \text { HIV-infected men } \\
\text { and } 106 \text { HIV-infected } \\
\text { women } \\
\text { Community-based, } \\
\text { Portugal }\end{array}$ & $\begin{array}{l}\text { Prevalence of MS } \\
\text { and its components } \\
\text { and determination of } \\
\text { whether patients with } \\
\text { or without CL have a } \\
\text { different prevalence } \\
\text { of MA }\end{array}$ & NA & $\begin{array}{l}\text {-There was no significant association with presence of CL and MS in either HIV- } \\
\text { infected women or men by ATPIII criteria: Women- prevalence of MS in women } \\
\text { with CL vs. w/o CL was } 25(46.3 \%) \text { vs. } 25(46.3 \%) ; p=0.854 ; \text { Men- prevalence of } \\
\text { MS in men with CL vs. w/o CL was } 84(54.5 \%) \text { vs. } 46(54.5 \% \text {.); } p=0.949 \\
\text {-No significant differences in HIV risk factors or in ART regimens were found } \\
\text { between patients with or without CL using ATPIII criteria } \\
\text { - In women, CL was significantly associated with higher odds of having MS as } \\
\text { defined by IDF with OR }=5.290(95 \% \mathrm{Cl} 1.502,18.635)\end{array}$ \\
\hline
\end{tabular}


Citation: Adekunle R, Bagchi S (2016) Review of Cardiovascular Disease in HIV-Infected Women. J AIDS Clin Res 7: 557. doi:10.4172/21556113.1000557

Page 8 of 12

\begin{tabular}{|c|c|c|c|c|c|}
\hline Study & Design & N Study Population & Outcome & $\begin{array}{l}\text { Follow up } \\
\text { (months) }\end{array}$ & Results \\
\hline $\begin{array}{l}\text { Womack et al. } \\
\text { [70]. }\end{array}$ & $\begin{array}{l}\text { Prospective, } \\
\text { observational } \\
\text { study }\end{array}$ & $\begin{array}{l}885 \text { HIV-infected and } \\
408 \text { HIV-uninfected } \\
\text { women } \\
\text { Urban, community- } \\
\text { based, USA, multiple } \\
\text { cities }\end{array}$ & $\begin{array}{l}\text { Associations between } \\
\text { progestin-only and } \\
\text { combined } \mathrm{HC} \text { and } \\
\text { parameters of glucose } \\
\text { and lipid metabolism }\end{array}$ & 60 months & $\begin{array}{l}\text {-Progestin-only } \mathrm{HC} \text { was associated with lower } \mathrm{HDL} \text { in HIV-infected as compared } \\
\text { with uninfected women }(-3 \mathrm{mg} / \mathrm{dl}(95 \% \mathrm{Cl}-5,-1 ; p=0.02) \text { and }-6 \mathrm{mg} / \mathrm{dl}(95 \% \mathrm{Cl} \\
-9,-1 ; p<0.0001) \text { respectively } \\
\text {-Progestin-only } \mathrm{HC} \text { was associated with higher HOMA-IR in HIV-infected and } \\
\text { HIV-uninfected women } 0.86(95 \% \mathrm{Cl} 0.51,1.22 ; p<0.0001) \text { and } 0.56(95 \% \mathrm{Cl} \\
0.12,1.01 ; p=0.01) \text { respectively } \\
\text {-Combined } \mathrm{HC} \text { was associated with higher } \mathrm{HDL} \text { in HIV-infected and uninfected } \\
\text { women } 5 \mathrm{mg} / \mathrm{dl}(95 \% \mathrm{Cl} 2,7 ; p=0.001) \text { and } 5 \mathrm{mg} / \mathrm{dl}(95 \% \mathrm{Cl} 3,7 ; p<0.0001) \\
\text { respectively }\end{array}$ \\
\hline $\begin{array}{l}\text { Parrinello et } \\
\text { al. [19]. }\end{array}$ & $\begin{array}{l}\text { Nested Case- } \\
\text { control study }\end{array}$ & $\begin{array}{l}1305 \text { HIV-infected } \\
\text { women and } 522 \text { HIV- } \\
\text { uninfected women - } \\
\text { Urban, community- } \\
\text { based, USA, multiple } \\
\text { cities }\end{array}$ & $\begin{array}{l}\text { Associations between } \\
\text { serum lipids and CIMT }\end{array}$ & NA & $\begin{array}{l}\text {-In HIV-uninfected women, higher TC }(2.17 \mathrm{mg} / \mathrm{d} ; \mathrm{Cl} 0.07,4.27 ; p=0.04), \mathrm{LDL}-\mathrm{C} \\
(3.46 \mathrm{mg} / \mathrm{d} ; 95 \% \mathrm{Cl} 1.02,5.90 ; p=0.01) \text {, and non-HDL-c }(2.40 \mathrm{mg} / \mathrm{d} ; 95 \% \mathrm{Cl} 0.36 \text {, } \\
4.44 ; p=0.02) \text { were associated with increased CIMT } \\
\text {-In HIV-infected women on ART, LDL-c }(2.27 \mathrm{mg} / \mathrm{d} ; 95 \% \mathrm{Cl} 0.19,4.35 ; p=0.03) \\
\text { and non-HDL-c (1.66 mg/d; } 95 \% \mathrm{Cl} 0.03,3.36 ; p=0.05) \text { were associated with } \\
\text { increased CIMT } \\
\text {-In HIV-infected women not on ART, no associations were seen between lipids } \\
\text { and CIMT }\end{array}$ \\
\hline $\begin{array}{l}\text { Adeyemi et al. } \\
\text { [71]. }\end{array}$ & $\begin{array}{l}\text { Cross- } \\
\text { sectional Study }\end{array}$ & $\begin{array}{l}95 \text { HIV-infected men } \\
\text { and } 26 \text { HIV-infected } \\
\text { women } \\
\text { Urban, community- } \\
\text { based, USA, Chicago }\end{array}$ & $\begin{array}{l}\text { Prevalence and } \\
\text { predictors of MS and } \\
\text { association between } \\
10 \text {-year FRS and MS }\end{array}$ & NA & $\begin{array}{l}\text {-Rates of MS did not differ by gender (males } 34 \% \text { and females } 36 \%) \\
\text {-FRS was higher in men than women }(11.8( \pm 7.1) \text { vs. } 3.1( \pm 2.8) ; p=0.001) \\
\text {-For components of MS, women had a higher prevalence of glucose intolerance } \\
\text { and increased WC }(p<0.001) \text { compared to men }\end{array}$ \\
\hline Tien et al. [72]. & $\begin{array}{l}\text { Observational, } \\
\text { prospective } \\
\text { study }\end{array}$ & $\begin{array}{l}1614 \text { HIV-infected and } \\
604 \text { HIV-uninfected } \\
\text { women } \\
\text { Urban, community- } \\
\text { based, USA, multiple } \\
\text { cities }\end{array}$ & $\begin{array}{l}\text { Associations between } \\
\text { type of ART, duration } \\
\text { of ART exposure, } \\
\text { and non-HIV-related } \\
\text { factors and IR using } \\
\text { HOMA }\end{array}$ & & $\begin{array}{l}\text {-Median FG levels were similar in HIV-infected and HIV-uninfected women (83 } \\
\text { mg/dL; } p=0.69 \text { ) } \\
\text {-HIV-infected women had higher median insulin levels ( } 11 \text { versus } 9 \mu \mathrm{IU} / \mathrm{mL} \text {; } \\
p<0.001) \\
\text {-HIV-infected women had higher median HOMA ( } 2.19 \text { versus } 1.83 ; p<0.001) \\
\text {-NRTI exposure was associated with a higher median HOMA compared to no } \\
\text { NRTI exposure in the adjusted analysis } 1.13(1.02 \text { to } 1.25) \\
\text {-HIV-infected women regardless of ART had higher HOMA compared to HIV- } \\
\text { uninfected after adjustment for cofounders ( } 1.91 \text { vs. } 2.07-2.30 \text { in various ART } \\
\text { groups) }\end{array}$ \\
\hline
\end{tabular}

NA: Not Applicable; Mass: Massachusetts; MS: Metabolic Syndrome; CIMT: Carotid Intimal Medial Thickness; VAT: Visceral Adipose Tissue; WC: Waist Circumference; CVR: Cardiovascular Risk; SD: Standard Deviation; TG: Triglycerides; FRS: Framingham Risk Score; CHD: Coronary Heart Disease; HDL: High Density Lipoprotein; HAART: Highly Active Antiretroviral Therapy; PI: Protease Inhibitor; CVD: Cardiovascular Disease; OR: Odds Ratio; BMI: Body Mass Index; d4T: Stavudine; NNRTI: Nonnucleoside Reverse Transcriptase Inhibitors; HOMA-IR: Homeostatic Model Assessment for Insulin Resistance; TC: Total Cholesterol; ART: Antiretroviral Therapy; CL: Clinical Lipodystrophy; ATPIII: Adult Treatment Panel III; IDF: International Diabetes Federation; HC: Hormonal Contraception; MA: Metabolic Abnormalities; FG: Fasting Glucose; NRTI: Nucleoside Reverse Transcriptase Inhibitor

Table 4: Studies assessing Metabolic Indices Contributing to Cardiovascular Risk.

but a lower prevalence of hypertension and obesity in HIV-infected women compared to HIV-uninfected women $(p<0.05)$ [10]. Mulligan et al. found that $40 \%$ of both HIV-infected and HIV-uninfected young women were overweight or obese (BMI $>25$ ), but there was no difference between groups. On the other hand, fasting TGs and total cholesterol (TC) levels were significantly worse among HIV-infected participants than HIV-negative participants. The authors concluded that obesity and dyslipidemia were prominent among HIV-infected adolescent women, and when coupled with other CV risk factors may accelerate the lifetime risk of CHD and other adverse events [30].

\section{Metabolic indices}

There were 15 studies included that evaluated metabolic indices in HIV-infected women. Metabolic syndrome was noted to be particularly prevalent in HIV-infected women. There are several definitions for metabolic syndrome but they all include insulin resistance, obesity, atherogenic dyslipidemia (elevations in TGs or low HDL) and hypertension. Sobieszczyk et al. found that HIV infection was independently associated with metabolic syndrome with a rate of $33 \% \mathrm{vs}$ $22 \%(\mathrm{p}<0.0001)$ in HIV-positive women compared with HIV-negative women [31]. Janiszewski et al. investigated the association between waist circumference (WC) and TG levels and CV risk and observed that HIV-infected women with high TG and WC had higher rates of metabolic syndrome than any other group $(p<0.05)[14]$. Another study in intravenous drug users observed that the prevalence of metabolic syndrome was significantly higher among HIV seropositive females than among seropositive males (29\% vs $10.3 \%, \mathrm{p}=0.013$ ) [32]. Mangili et al. showed that HIV-infected women had higher rates of metabolic syndrome compared to HIV-infected men, and mean common CIMT measurements were higher among those with metabolic syndrome than those without metabolic syndrome $(0.66 \mathrm{~mm}$ vs. $0.59 \mathrm{~mm}$; $\mathrm{p}=0.005)$ [20]. However, other studies did not consistently demonstrate increased rates of metabolic syndrome in seropositive women compared to men, nor that increased rates of metabolic syndrome was consistently associated with increased CHD risk (Table 4).

\section{Markers of inflammation and immune activation}

There were eight studies that investigated markers of inflammation and immune activation in HIV-infected women. Conceivably, HIVinfected patients may have higher rates and increased risk of CHD because of increased levels of inflammation and immune activation than seronegative patients. This increased immune activation persists even in patients on ART who have achieved virological suppression and immune reconstitution with CD4 cell count $>200 \mathrm{~mm}^{3}$ [33]. Soluble CD163 (sCD163) is a monocyte-macrophage specific scavenger receptor cleaved from activated monocytes and macrophages during inflammation, and elevated levels have been associated with coronary artery disease in the general population and HIV-infected men suggesting this inflammatory and immune pathway may be involved in the pathogenesis of atherosclerosis $[34,35]$. Fitch et al. reported that sCD163 levels were significantly higher in HIV-infected females than HIV-infected and non-infected males [26]. 98\% of the women were on 
ART with a median duration of eight years and $84 \%$ had undetectable viral loads. Shaked et al. demonstrated elevated levels of sCD163 in HIV-infected and HIV/hepatitis C co-infected women, though $46 \%$ of total study cohort ( $29 \%$ of HIV+/HCV- cohort and $17 \%$ of $\mathrm{HIV}+1$ $\mathrm{HCV}+$ cohort) were not on ART and the median viral load was 885 copies/mL [36].

Kaplan et al. compared changes in several inflammatory markers in $127 \mathrm{HIV}$-infected women and matched control women before and after Highly Active Antiretroviral Therapy (HAART) initiation in the Women's Interagency HIV Study (WIHS). They found that HIVinfected women had statistically significant higher levels of tumor necrosis factor (TNF)-alpha, soluble interleukin (IL)-2 receptor, IL-10, monocyte chemoattractant protein (MCP)-1 and D-dimer prior to ART initiation, and though the levels of TNF-alpha and soluble IL-2 receptor decreased among HIV-infected women after ART these levels remained higher than in HIV-uninfected women. These studies demonstrating higher levels of plasma markers of inflammation and immune activation in HIV-infected women provide a potential mechanism by which these women could have increased rates of subclinical atherosclerosis and CHD [37].

\section{Highly active antiretroviral therapy (HAART)}

There were 12 studies that evaluated the association of HAART and CHD in HIV-infected women, and selected ones were listed in Table 3. Studies in predominantly male cohorts suggest that ART, particularly protease inhibitors, is an independent risk factor for increased CHD [38,39]. Abacavir $(A B C)$ has also been implicated in increased risk of and rates of cardiovascular events though results have been mixed among studies, [5,40-43]. These studies, however, again included predominantly male populations. In a study of 2187 women of whom 710 were HIV infected, Womack et al. found no association between ART and CVD outcomes [10]. Conversely, Chow et al. observed that longer duration of any ART regimen was associated with significantly decreased risk of strokes (HR 0.80; 95\% CI 0.73, 0.88, $\mathrm{p}=<0.001$ ) [12]. Therefore, it not clear whether ART exposure or specific antiretroviral medications (ARVs) truly increase rates of CVD in HIV-infected women.

Studies also evaluated the contribution of ART and specific ARVs to changes in traditional CHD risk factors and markers of inflammation. Estrada et al. demonstrated that HIV-infected women receiving nonnucleoside reverse transcriptase inhibitor (NNRTI)-based regimens had better lipid profiles than HIV-infected women on PI-based regimens [44]. Shaffer et al. evaluated CHD risk factors following initiation of NNRTI vs. PI-based ART in women from 7 countries in sub-Saharan Africa over 144 weeks. ART with either nevirapine or lopinavir/ ritonavir had similar lipid values with only TC increasing at 144 weeks $(p=0.090)$ [45]. However, Tien et al. found no significant associations between ART and lipid values [46]. As such, the contribution of ARVs to lipid profiles remain uncertain.

Shikuma et al. looked at high sensitivity C-reactive protein (hsCRP) and its association with efavirenz (EFV) versus $A B C$ over a 96 week period in HIV-infected women and men. Levels of hsCRP did not differ by gender at baseline, but by week 96 women had higher levels of hsCRP than men (median $6 \mathrm{mg} /$ liter vs. median $1.6 \mathrm{mg} /$ liter, $\mathrm{p}<0.001$ ), but no difference was noted between the EFV and ABC groups $(\mathrm{p}=0.38)$ [47]. Another study investigated the effects of ART on plasma markers of inflammation in HIV-infected and uninfected women and demonstrated that markers of inflammation decreased among HIV-infected women after ARV initiation, but levels of TNF-alpha and IL-2 remained elevated among HIV-infected women compared to uninfected women over time despite ART ( $p<0.0001$ and $p<0.01$ respectively) [37]. It remains indeterminate to what degree plasma markers of inflammation and immune activation change with ART use and specific ARVs and whether these changes differ by gender.

\section{Discussion}

HIV-infected patients have increased rates of CHD compared to the general population, and these increased rates have been more frequently reported in HIV-infected men than in women. Freiberg et al looked at the veteran population and found an increase rate of cardiovascular events in HIV-infected male veterans compared with HIV-uninfected male veterans HR 1.48 (95\% CI, 1.27-1.72) [3]. Similarly, Silverberg et al demonstrated a $44 \%$ increased risk of MIs among a predominately male HIV-infected population compared with a predominately male HIV-uninfected population [48]. Studies that included both male and female participants have mostly demonstrated that either gender was not a risk factor for development of CHD or that male rather than female gender was a risk factor for CHD in HIVinfected patients $[9,11-12,32,49,50]$. Differences in gender as a risk factor for CHD among studies in HIV-infected patients may be due to differences in study population as well as the vast majority of studies in which women were underrepresented. What this review highlights though is that HIV-infected women do have increased rates of AMI and ischemic stroke compared to HIV-uninfected women, and may also be increased compared to HIV-infected men as observed in some studies despite women being projected to have lower CHD risk based on FRS.

Studies assessing CHD risk by measuring anatomical or physiological measures of subclinical atherosclerosis have reported mixed results. Of these, studies using CTA have consistently demonstrated increased coronary atherosclerosis particularly noncalcified plaques in asymptomatic HIV-infected women without known CV risk compared to uninfected women highlighting the presence of subclinical atherosclerosis in these women. Similarly, CTA has demonstrated high risk morphology plaque types in asymptomatic HIV-infected males [51].

Potential explanations for the increased rates of CVD and subclinical atherosclerosis may be partly explained by increased levels of inflammation and immune activation in HIV-infected women despite virological suppression on ART. While studies have suggested that ART, particularly PIs, increase the risk of cardiovascular disease in HIVinfected men, the contribution of ART to clinical or subclinical CHD in seropositive women remains uncertain due to conflicting results among the number of limited studies available. It appears unlikely, however, that disproportionate representation of traditional CHD risk factors and metabolic indices among HIV-infected women can explain well the observed increased rates of CHD given the inconsistent findings of the prevalence of $\mathrm{CV}$ risk factors reported among studies.

Potential reasons for conflicting results among studies of surrogate measures of subclinical atherosclerosis could be heterogeneous study designs and study populations with varying periods of followup. Additionally, different outcomes were measured making it hard to compare studies directly. Many studies were of short duration, which makes it difficult to detect associations with chronic disease processes with cumulative risk such as CVD. Finally, the median age in most studies of HIV-infected women was young posing a challenge in detecting subclinical CVD, which is generally considered a co-morbidity of aging. Nonetheless, it is important to identify and validate surrogate measures of subclinical CVD as these test results 
may be useful in further risk stratifying HIV-infected patients to maximize preventive measures to prevent clinical CHD events. The most promising surrogate measure of subclinical CHD currently may be the CTA, and larger studies to investigate this imaging modality in HIV-infected women seems warranted based on the suboptimal performance of other available surrogate measures. How to best assess the risk of CHD in HIV-infected women remains uncertain.

There are significant concerns that FRS does not accurately estimate CHD risk in HIV women. The D:A:D score has been suggested to be more accurate in HIV-infected patients because it accounts for history of exposure to ART [52]. However, it too has limitations because the original data used to develop the D:A:D score was obtained between 1999 and 2002 in a predominately male population and there have been dramatic changes in ART regimens since then. Thus it is not clear whether the D:A:D score will remain accurate, and no studies have evaluated it in the era of newer ARVs and specifically in women. When compared with the FRS, the Reynolds score was shown to be more accurate when assessing 10-year CV risk for women [53]. There are no studies using Reynolds score to assess CV risk in HIV-infected women, however. These limitations of our current risk assessment tools reinforce the need to identify and validate risk assessment tools and surrogate measures of clinical and subclinical atherosclerosis in HIVinfected women.

Elucidating the mechanisms for increased rates of $\mathrm{CHD}$ and increased risk of CHD in HIV-infected women remains a challenge due to the heterogeneity of study designs, study populations, sample sizes, and outcomes measured. There is a suggestion that metabolic syndrome characterized by insulin resistance may be more prevalent in HIV-infected women, and dyslipidemia appears to be more prominent though inconsistently so compared to HIV-uninfected women and HIV-infected men. Also, some markers of inflammation and immune activation appear to be elevated in HIV-infected women compared to HIV-uninfected women even after virological suppression has been achieved. sCD163 is of particular interest as it has been associated with coronary artery disease in the general population [54]. Another important potential factor contributing to premature, increased CHD risk that has not been extensively evaluated in the literature is the effects of menopause since HIV-infected women have been reported to undergo premature menopause secondary to loss of ovarian function at an earlier age $[55,56]$.

There were several strengths of our review. It presented a comprehensive review of the current literature on the associations of HIV infection and CHD outcomes- namely, both clinical and subclinical surrogate measures of atherosclerosis- in women. We reviewed the prevalence of traditional CHD risk factors among HIVinfected women and compared them to HIV-uninfected women and HIV-infected men, and focused on other important potential mechanisms that may explain the reported associations with CHD, surrogate measures of CVD, and metabolic diseases that increase risk of CHD. Finally, the studies included ranged from urban hospital-based to rural community-based populations in the United States, Europe, Australia, sub-Saharan Africa, and Brazil thereby making the findings generalizable. One limitation of our review was that the review period was restricted to the past 10 years, though most data relevant to the current ART era were well-represented in that time period. Also, we did not perform a systematic meta-analysis but it would have been difficult to perform such an analysis given the scope of our review reporting on a wide range of endpoints such as clinical outcomes, surrogate measures of atherosclerosis, and risk factors.
In summary, HIV-infected women have increased rates of CHD compared to HIV-uninfected women and likely even HIV-infected men. However, there are no well-validated risk assessment tools or surrogate measures of subclinical CHD among HIV-infected to help identify high-risk women for targeting more intensive preventive measures. Additionally, our understanding of the biological and other reasons for the observed disparate $\mathrm{CHD}$ rates remains limited. Future studies that include large numbers of HIV-infected women with extended follow-up periods using surrogate measure of CVD and investigating pathogenic mechanisms underlying these observations are urgently needed.

\section{Acknowledgments}

No grant funding was used for this study. The authors want to thank Shana Burrowes for technical assistance during manuscript preparation. All authors critically reviewed the manuscript and approve the final version of the manuscript.

\section{References}

1. Cockerham L, Scherzer R, Zolopa A, Rimland D, Lewis CE, et al. (2010) Association of HIV infection, demographic and cardiovascular risk factors with all-cause mortality in the recent HAART era. J Acquir Immune Defic Syndr 53: 102-106.

2. French AL, Gawel SH, Hershow R, Benning L, Hessol NA, et al. (2009) Trends in mortality and causes of death among women with HIV in the United States: a 10-year study. J Acquir Immune Defic Syndr 51: 399-406.

3. Petoumenos K, Reiss P, Ryom L, Rickenbach M, Sabin CA, et al. (2014) Increased risk of cardiovascular disease (CVD) with age in HIV-positive men: a comparison of the D:A:D CVD risk equation and general population CVD risk equations. HIV Med 15: 595-603.

4. Freiberg MS, Chang CC, Kuller LH, Skanderson M, Lowy E, et al. (2013) HIV infection and the risk of acute myocardial infarction. JAMA Intern Med 173: 614-622.

5. Bozzette SA, Ake CF, Tam HK, Phippard A, Cohen D, et al. (2008) Long-term survival and serious cardiovascular events in HIV-infected patients treated with highly active antiretroviral therapy. J Acquir Immune Defic Syndr 47: 338-341.

6. Go AS, Mozaffarian D, Roger VL, Benjamin EJ, Berry JD, et al. (2013) Heart disease and stroke statistics--2013 update: a report from the American Heart Association. Circulation 127: e6-e245.

7. George J, Rapsomaniki E, Pujades-Rodriguez M, Shah AD, Denaxas S, et al. (2015) How Does Cardiovascular Disease First Present in Women and Men? Incidence of 12 Cardiovascular Diseases in a Contemporary Cohort of 1,937,360 People. Circulation 132: 1320-1328.

8. Heart Disease Facts and Statistics. CDC

9. Triant VA, Lee H, Hadigan C, Grinspoon SK (2007) Increased acute myocardial infarction rates and cardiovascular risk factors among patients with human immunodeficiency virus disease. J Clin Endocrinol Metab 92: 2506-2512.

10. Womack JA, Chang CC, So-Armah KA, Alcorn C, Baker JV, et al. (2014) HIV infection and cardiovascular disease in women. J Am Heart Assoc 3: e001035.

11. Lang S, Mary-Krause M, Cotte L, Gilquin J, Partisani M, et al. (2010) Increased risk of myocardial infarction in HIV-infected patients in France, relative to the general population. AIDS 24: 1228-1230.

12. Chow FC, Regan S, Feske S, Meigs JB, Grinspoon SK, et al. (2012) Comparison of ischemic stroke incidence in HIV-infected and non-HIV-infected patients in a US health care system. J Acquir Immune Defic Syndr 60: 351-358.

13. Tardif JC, Heinonen T, Orloff D, Libby $P$ (2006) Vascular biomarkers and surrogates in cardiovascular disease. Circulation 113: 2936-2942.

14. Janiszewski PM, Ross R, Despres JP, Lemieux I, Orlando G, et al. (2011) Hypertriglyceridemia and waist circumference predict cardiovascular risk among HIV patients: a cross-sectional study. PLoS One 6: e25032.

15. Mondy KE, de las Fuentes L, Waggoner A, Onen NF, Bopp CS, et al. (2008) Insulin resistance predicts endothelial dysfunction and cardiovascular risk in HIV-infected persons on long-term highly active antiretroviral therapy. AIDS 22: 849-856.

16. Law M, Friis-Møller N, Weber R, et al. Reiss P, Thiebaut R, et al. (2003) 
Modelling the 3-year risk of myocardial infarction among participants in the Data Collection on Adverse Events of Anti-HIV Drugs (DAD) study. HIV Med 4:1-10.

17. Rohani M, Jogestrand T, Ekberg M, van der Linden J, Källner G, et al. (2005) Interrelation between the extent of atherosclerosis in the thoracic aorta, carotid intima-media thickness and the extent of coronary artery disease. Atherosclerosis 179: 311-316

18. Johnsen S, Dolan SE, Fitch KV, Kanter JR, Hemphill LC, et al. (2006) Carotid intimal medial thickness in human immunodeficiency virus-infected women: effects of protease inhibitor use, cardiac risk factors, and the metabolic syndrome. J Clin Endocrinol Metab 91: 4916-4924.

19. Parrinello CM, Landay AL, Hodis HN, Gange SJ, Norris PJ, et al. (2012) Association of subclinical atherosclerosis with lipid levels amongst antiretroviraltreated and untreated HIV-infected women in the Women's Interagency HIV study. Atherosclerosis 225: 408-411.

20. Mangili A, Jacobson DL, Gerrior J, Polak JF, Gorbach SL, et al. (2007) Metabolic syndrome and subclinical atherosclerosis in patients infected with HIV. Clin Infect Dis 44: 1368-1374.

21. Anderson TJ (2006) Arterial stiffness or endothelial dysfunction as a surrogate marker of vascular risk. Can J Cardiol 22 Suppl B: 72B-80B.

22. Eira M, Bensenor IM, Dorea EL, Cunha RS, Mill JG, et al. (2012) Potent antiretroviral therapy for human immunodeficiency virus infection increases aortic stiffness. Arq Bras Cardiol 99: 1100-1107.

23. Lazar JM, Wu X, Shi Q, Kagame A, Cohen M, et al. (2009) Arterial wave reflection in HIV-infected and HIV-uninfected Rwandan women. AIDS Res Hum Retroviruses 25: 877-882.

24. Miller JM, Rochitte CE, Dewey M, Arbab-Zadeh A, Niinuma H, et al. (2008) Diagnostic performance of coronary angiography by 64 -row CT. N Engl J Med 359: 2324-2336.

25. Hoffmann U, Truong QA, Schoenfeld DA, Chou ET, Woodard PK, et al. (2012) Coronary CT angiography versus standard evaluation in acute chest pain. N Engl J Med 367: 299-308.

26. Fitch KV, Srinivasa S, Abbara S, Burdo TH, Williams KC, et al. (2013) Noncalcified coronary atherosclerotic plaque and immune activation in HIVinfected women. J Infect Dis 208: 1737-1746.

27. Finn AV, Nakano M, Narula J, Kolodgie FD, Virmani R (2010) Concept of vulnerable/unstable plaque. Arterioscler Thromb Vasc Biol 30: 1282-1292.

28. Mangili A, Gerrior J, Tang AM, O'Leary DH, Polak JK, et al. (2006) Risk of cardiovascular disease in a cohort of HIV-infected adults: a study using carotid intima-media thickness and coronary artery calcium score. Clin Infect Dis 43:1482-1489.

29. Sharma A, Holman S, Pitts R, Minkoff HL, Dehovitz JA, et al. (2007) Peripheral arterial disease in HIV-infected and uninfected women. HIV Med 8: 555-560.

30. Mulligan K, Harris DR, Monte D, Stoszek S, Emmanuel P, et al. (2010) Obesity and dyslipidemia in behaviorally HIV-infected young women: Adolescent Trials Network study 021. Clin Infect Dis 50: 106-114.

31. Sobieszczyk ME, Hoover DR, Anastos K, Mulligan K, Tan T, et al. (2008) Prevalence and predictors of metabolic syndrome among HIV-infected and HIV-uninfected women in the Women's Interagency HIV Study. J Acquir Immune Defic Syndr 48: 272-280.

32. Baum MK, Rafie C, Lai S, Xue L, Sales S, et al. (2006) Coronary Heart Disease (CHD) Risk Factors and Metabolic Syndrome in HIV-Positive Drug Users in Miami. Am J Infect Dis 2: 173-179.

33. Alcaide ML, Parmigiani A, Pallikkuth S, Roach M, Freguja R, et al. (2013) Immune activation in HIV-infected aging women on antiretrovirals--implications for age-associated comorbidities: a cross-sectional pilot study. PLoS One 8: e63804

34. Aristoteli LP, Møller HJ, Bailey B, Moestrup SK, Kritharides L (2006) The monocytic lineage specific soluble CD163 is a plasma marker of coronary atherosclerosis. Atherosclerosis 184: 342-347.

35. Burdo TH, Lo J, Abbara S, Wei J, DeLelys ME, et al. (2011) Soluble CD163, a novel marker of activated macrophages, is elevated and associated with noncalcified coronary plaque in HIV-infected patients. J Infect Dis 204: 12271236.

36. Shaked I, Hanna DB, Gleißner C, Marsh B, Plants J, et al. (2014) Macrophage inflammatory markers are associated with subclinical carotid artery disease in women with human immunodeficiency virus or hepatitis $C$ virus infection. Arterioscler Thromb Vasc Biol 34: 1085-1092.

37. Kaplan RC, Landay AL, Hodis HN, Gange SJ, Norris PJ, et al. (2012) Potential cardiovascular disease risk markers among HIV-infected women initiating antiretroviral treatment. J Acquir Immune Defic Syndr 60: 359-368.

38. Mary-Krause M, Cotte L, Simon A, Partisani M, Costagliola D; Clinical Epidemiology Group from the French Hospital Database (2003) Increased risk of myocardial infarction with duration of protease inhibitor therapy in HIVinfected men. AIDS 17: 2479-2486.

39. Holmberg SD, Moorman AC, Williamson JM, Tong TC, Ward DJ, et al. (2002) Protease inhibitors and cardiovascular outcomes in patients with HIV-1. Lance 360: 1747-1748.

40. Worm SW, Sabin C, Weber R, Reiss P, El-Sadr W, et al. (2010) Risk of Myocardial Infarction in Patients with HIV Infection Exposed to Specific Individual Antiretroviral Drugs from the 3 Major Drug Classes: The Data Collection on Adverse Events of Anti-HIV Drugs (D:A:D) Study. J Infect Dis 201: 318-330.

41. Sabin CA, Worm SW, Weber R, Reiss P, El-Sadr W, et al. (2008) Use of nucleoside reverse transcriptase inhibitors and risk of myocardial infarction in HIV-infected patients enrolled in the D:A:D study: a multi-cohort collaboration. Lancet 371: 1417-1426.

42. Martin A, Bloch M, Amin J, Baker D, Cooper DA, et al. (2009) Simplification of antiretroviral therapy with tenofovir-emtricitabine or abacavir-Lamivudine: a randomized, 96-week trial. Clin Infect Dis 49: 1591-1601.

43. Bedimo RJ, Westfall AO, Drechsler H, Vidiella G, Tebas P (2011) Abacavir use and risk of acute myocardial infarction and cerebrovascular events in the highly active antiretroviral therapy era. Clin Infect Dis 53: 84-91.

44. Estrada V, Geijo P, Fuentes-Ferrer M, Alcalde ML, Rodrigo M, et al. (2011) Dyslipidaemia in HIV-infected women on antiretroviral therapy. Analysis of 922 patients from the Spanish VACH cohort. BMC Womens Health 11: 36.

45. Shaffer D, Hughes MD, Sawe F, Bao Y, Moses A, et al. (2014) Cardiovascular Disease Risk Factors in HIV-Infected Women Following Initiation of Lopinavir/ ritonavir- and Nevirapine-based Antiretroviral Therapy in Sub-Saharan Africa. JAIDS J Acquir Immune Defic Syndr 66: 155-163

46. Tien PC, Schneider MF, Cox C, Cohen M, Karim R, et al. (2010) HIV, HAART, and lipoprotein particle concentrations in the Women's Interagency HIV Study. AIDS 24: 2809-2817

47. Shikuma CM, Ribaudo HJ, Zheng Y, Gulick RM, Meyer WA, (2011) et al. Change in high-sensitivity c-reactive protein levels following initiation of efavirenz-based antiretroviral regimens in HIV-infected individuals. AIDS Res Hum Retroviruses 27: $461-468$

48. Silverberg MJ, Leyden WA, Xu L, Horberg MA, Chao CR, et al. (2014) Immunodeficiency and risk of myocardial infarction among HIV-positive individuals with access to care. J Acquir Immune Defic Syndr 65: 160-166.

49. Seaberg EC, Benning L, Sharrett AR, Lazar JM, Hodis HN, et al. (2010) Association between human immunodeficiency virus infection and stiffness of the common carotid artery. Stroke 41: 2163-2170.

50. Parrinello CM, Sinclair E, Landay AL, Lurain N, Sharrett AR, et al. (2012) Cytomegalovirus immunoglobulin $\mathrm{G}$ antibody is associated with subclinical carotid artery disease among HIV-infected women. J Infect Dis 205: 1788-1796.

51. Lo J, Abbara S, Shturman L, Soni A, Wei J. et al. (2010) Increased prevalence of subclinical coronary atherosclerosis detected by coronary computed tomography angiography in HIV-infected men. AIDS 24: 243-253

52. Friis-Møller N, Thiébaut R, Reiss P, Weber R, Monforte AD, et al. (2010) Predicting the risk of cardiovascular disease in HIV-infected patients: the data collection on adverse effects of anti-HIV drugs study. Eur J Cardiovasc Prev Rehabil 17: 491-501.

53. Cook NR, Paynter NP, Eaton CB, Manson JE, Martin LW, et al. (2012) Comparison of the Framingham and Reynolds Risk scores for global cardiovascular risk prediction in the multiethnic Women's Health Initiative. Circulation 125: 1748-1756, S1-11.

54. Moreno JA, Muñoz-García B, Martín-Ventura JL, Madrigal-Matute J, Orbe J, et al. (2009) The CD163-expressing macrophages recognize and internalize TWEAK: potential consequences in atherosclerosis. Atherosclerosis 207: 103110. 
Citation: Adekunle R, Bagchi S (2016) Review of Cardiovascular Disease in HIV-Infected Women. J AIDS Clin Res 7: 557. doi:10.4172/21556113.1000557

55. Imai K Sutton MY2, Mdodo R3, Del Rio C4 (2013) HIV and Menopause: A Systematic Review of the Effects of HIV Infection on Age at Menopause and the Effects of Menopause on Response to Antiretroviral Therapy. Obstet Gyneco Int 2013: 340309.

56. Cecilia B, Rosario R, Antonio B, Stefano Z, Federica C, et al. (2014) Menopause in HIV Infected Women: A Comprehensive Approach to Physical and Psychological Health. J Osteoporos Phys Act 2:117.

57. Hessamfar-Bonarek M, Morlat P, Salmon D, Cacoub P, May T, et al. (2010) Causes of death in HIV-infected women: persistent role of AIDS. The 'Mortalité 2000 \& 2005' Surveys (ANRS EN19). Int J Epidemiol 39: 135-146.

58. Fuchs SC, Alencastro PR, Ikeda ML, Barcellos NT, Wolff FH, et al. (2013) Risk of coronary heart disease among HIV-infected patients: a multicenter study in Brazil. ScientificWorldJournal 163418

59. Lake JE, Wohl D, Scherzer R, Grunfeld C, Tien PC, et al. (2011) Regional fat deposition and cardiovascular risk in HIV infection: the FRAM study. AIDS Care 23: 929-938.

60. Kaplan RC, Kingsley LA, Sharrett AR, Li X, Lazar J, et al. (2007) Ten-year predicted coronary heart disease risk in HIV-infected men and women. Clin Infect Dis 45: 1074-1081.

61. Aboud M, Elgalib A, Pomeroy L, Panayiotakopoulos G, Skopelitis E, et al. (2010) Cardiovascular risk evaluation and antiretroviral therapy effects in an HIV cohort: implications for clinical management: the CREATE 1 study. Int J Clin Pract 64: 1252-1259.

62. Seaberg EC, Benning L, Sharrett AR, Lazar JM, Hodis HN, et al. (2010) Association between human immunodeficiency virus infection and stiffness of the common carotid artery. Stroke 41: 2163-2170.

63. Karim R, Mack WJ, Kono N, Tien PC, Anastos K, et al. (2013) Gonadotropin and sex steroid levels in HIV-infected premenopausal women and their association with subclinical atherosclerosis in HIV-infected and uninfected women in the women's interagency HIV study (WIHS). J Clin Endocrinol Metab 98: E610-E618.
64. Parrinello CM, Sinclair E, Landay AL, Lurain N, Sharrett AR, et al. (2012) Cytomegalovirus immunoglobulin $\mathrm{G}$ antibody is associated with subclinical carotid artery disease among HIV-infected women. J Infect Dis 205: 17881796.

65. Kroll AF, Sprinz E, Leal SC, Labrêa Mda G, Setúbal S (2012) Prevalence of obesity and cardiovascular risk in patients with HIVIAIDS in Porto Alegre, Brazil. Arq Bras Endocrinol Metabol 56: 137-141.

66. Mateen FJ, Kanters S, Kalyesubula R, Mukasa B, Kawuma E, et al. (2013) Hypertension prevalence and Framingham risk score stratification in a large HIV-positive cohort in Uganda. J Hypertens 31: 1372-1378.

67. Kaplan RC, Sinclair E, Landay AL, Lurain N, Sharrett AR, et al. (2011) T cell activation and senescence predict subclinical carotid artery disease in HIVinfected women. J Infect Dis 203: 452-463.

68. Pullinger CR, Aouizerat BE, Gay C, Coggins T, Movsesyan I, et al. (2010) Metabolic abnormalities and coronary heart disease risk in human immunodeficiency virus-infected adults. Metab Syndr Relat Disord 8: 279286

69. Freitas P, Carvalho D, Souto S, Santos AC, Xerinda S, et al. (2011) Impact of Lipodystrophy on the prevalence and components of metabolic syndrome in HIV-infected patients. BMC Infect Dis 11: 246.

70. Womack JA, Scherzer R, Cole SR, Fennie K, Williams AB, et al. (2009) Hormonal contraception and metabolic outcomes in women with or at risk for HIV infection. J Acquir Immune Defic Syndr 52: 581-587.

71. Adeyemi O, Rezai K, Bahk M, Badri S, Thomas-Gossain N (2008) Metabolic syndrome in older HIV-infected patients: data from the CORE50 cohort. AIDS Patient Care STDS 22: 941-945.

72. Tien PC, Schneider MF, Cole SR, Levine AM, Cohen M, et al. (2008)Antiretroviral therapy exposure and insulin resistance in the Women's Interagency HIV study. J Acquir Immune Defic Syndr 49: 369-376. 